\title{
Sobre los carros con copa de Baiões
}

\author{
Thomas G. SCHATTNER \\ Instituto Arqueológico Alemán (Madrid)
}

\begin{abstract}
Resumen
Los carros con copas (Kesselwagen) encontrados en el año 1983 en Baiões, centro de Portugal, y luego publicados en 1984, son parte de un amplio complejo de hallazgos con más de 80 componentes, que aunque no estando cerrado, ha sido calificado como depósito.

La investigación se ha ocupado desde entonces de forma intensa con el hallazgo. Con respecto a los carros con copas se les está valorizando no solamente como indicadores, sino como testigos principales para una influencia mediterránea en la Lusitania central durante la época del Bronce Final.
\end{abstract}

Sin embargo, la presente investigación muestra de forma contundente, que los carros con copas de Baiões tienen una conexión con el centro de Europa, especialmente con la región meridional de los Alpes, hacia la cual hasta ahora se conocen pocos contactos arqueológicos.

También en Lusitania se utilizarían como utensilios en el culto. Como lugar de colocación son mejor imaginables los santuarios que las tumbas de la región. Su apariencia estaría ligada a la introducción de carros, o sus representaciones en general, que surgen de forma impetuosa en la Hispania del oeste y suroeste durante el siglo VII a. C., como se observa tanto en el arte rupestre como en las conocidas estelas extremeñas, en las que aparecen carros con cierta abundancia. Todo indica, que carros ejercieron una especial atracción sobre las sociedades del oeste y suroeste hispánicos, que sale a ponerse de manifiesto en aquel momento de cambio del final de la época del bronce e inicio del hierro, época acompañado de grandes cambios, cuando se buscan nuevas formas de expresión.

Palabras clave: carros con copas - Kesselwagen - Baiões - bronce - tumbas - santuarios - carros - representaciones de carros - arte rupestre - estelas extremeñas

\section{Summary}

The miniature carts carrying vessels or cups (Kesselwagen) found in Baiões/Portugal in 1983, and quickly published in 1984, form part of a bigger ensemble with more than 80 single parts, which has been called a deposit, although it isn't closed. It has been the object for quite a lot of investigation. As for the carts, the opinion is clearly predominant, that they are not only indicators, but witnesses for mediterranean influence in the mid west Lusitanian region at the end of the bronze age.

In the contrary, this contribution shows clearly, that the carts have a strong connection to Central Europe, specially to the southern Alpes region, to which only few archaeological contacts are known until now. Also in Lusitania the carts are to be used as a cult device. As a place for the use, santuaries are better imaginable than the tombs of the region. Their appearance are here connected with the introduction of carts, respectively with their representations, coming up pushingly during the 7th century B.C. in southwestern Hispania, as is shown by representations in rock art, but specially by the so called extremenian stelae, on which a grate number of them are depicted. As it seems, carts were highly attractive for indigenous societies of the hispanic west and southwest as a means of representation, when a demand for new patterns of expression emerged at the transition from the final bronze age to iron age, a period characterised by big changes.

Keywords: carts carrying vessels - Baiões - bronze - tombs - sanctuaries - carts - representations of carts - rock engravings - extremenean stelae. 


\section{Preámbulo}

Dedico esta contribución a mi amigo Manuel Bendala no solamente en reconocimiento de sus grandes méritos científicos, que tiene para el avance de la arqueología dentro y sobre todo también fuera de España, sino también en su calidad de amigo, esperando que el tema le interese, ya que en muchas ocasiones lo ha tratado desde diferentes perspectivas.

El mundo antiguo estaba estructurado espacialmente en regiones ${ }^{1}$. Las regiones eran más o menos extensas, y los límites estaban determinados en gran medida por el entorno natural y la presencia de valles o llanuras, montañas o vegas fluviales, lagos o mares. Los hallazgos arqueológicos correspondientes parecen estar igualmente diseminados y diferenciados ${ }^{2}$. El reciente debate acerca del carácter del área del Mediterráneo, que Fernand Braudel había interpretado como un espacio homogéneo, pero que Peregrine Horden y Nicholas Purcell consideran ahora una acumulación de regiones que conforman el espacio común a través de la sintonía y el conflicto, el intercambio y la delimitación, gira precisamente en torno a ese problema ${ }^{3}$. Los desarrollos con una propagación trascedente, es decir, la participación de pueblos muy distantes entre sí en un mismo fenómeno cultural y la asimilación correspondiente por parte de sus habitantes, lo que, arqueológicamente, se pone de manifiesto en un patrimonio de formas común y unificado, comienzan en el Bronce Final, convirtiéndose enseguida en la norma.

Así, por ejemplo, en el entorno greco-feniciomediterráneo de Levante, Anatolia y el Egeo de esta época se crea, junto a una koiné iconográfica y figurativa, que más tarde encontró probablemente su mejor expresión en el estilo orientalizante, un patrimonio de formas común incluso en

1 En primer lugar, quiero dar las gracias a mis colegas Michael Blech y Philine Kalb por su interés y ayuda en la elaboración del manuscrito, así como por sus consejos y observaciones. La versión alemana de esta contribución aparecerá en Madrider Mitteilungen, vol. 52.

2 Véase, p. ej., el exhaustivo estudio de los hallazgos de la Edad del Hierro a ambos lados de la cordillera gallega, v. Carballo Arceo 2003.

3 Braudel 1993; Horden - Purcell 2000; v. ahora las actas del Congreso, Harris 2005, Allison 2009 y Rouillard 2009.

4 p. ej., Schattner 2007, 486. la >cerámica doméstica ${ }^{4}$. La amplitud del espectro de hallazgos y la abundancia de los mismos permite determinar las conexiones con relativa seguridad.

La situación es distinta, sin embargo, en regiones como las del norte y el oeste del ámbito indoeuropeo, donde no surgió una koiné comparable a pesar de que los primeros contactos lejanos se produjeron ya en él Bronce Final, según se ha observado $^{5}$. En este caso se trata siempre de hallazgos individuales, de piezas sobresalientes, adecuadas para señalar las citadas conexiones, tal como sucede con la difusión de los monumentos iconográficos tempranos ${ }^{6}$. No obstante, su fuerza argumentativa es considerablemente más débil; atendiendo al carácter masivo de los hallazgos autóctonos, a la grandiosidad de dichos monumentos se opone, estadísticamente, su número reducido.

Precisamente por ello, los estudios que investigan dichas piezas adquieren una importancia mayor. Hoy en día se conoce la existencia de, al menos, tres carros con copa de finales de la Edad del Bronce, que han sido hallados en la localidad de Baiões, situada en el centro de Portugal, y que son los únicos ejemplares conservados en la Península Ibérica ${ }^{7}$. De momento falta un estudio detallado de su posición tipológica y de su clasificación cultural. El presente artículo pretende hacer una contribución a ese respecto.

\section{El TESORO DE BAIÕES}

En 1983 se halló en Portugal uno de los depósitos prehistóricos más extensos de la Edad del Bronce. El hallazgo se produjo en la ladera oriental del castro de Nossa Senhora da Guía, en el municipio de Baiões (São Pedro do Sul, Viseu, Portugal), durante la construcción de una fuente

5 p. ej., Coffyn - Sion 1993 o Vilaça 2008, 31 con más bibliografía.

6 Parzinger 1991.

7 También en el Occidente indoeuropeo son escasos los hallazgos de este tipo, v. Coffyn - Gómez - Mohen 1981, 23 con remisión a la fig. 7 de la rueda del carro hallado en el depósito de Vénat. En el presente artículo no se han tenido en cuenta los restantes carros en miniatura de distintos tipos encontrados en la Península Ibérica. Recopilación, p. ej., en Almagro-Gorbea 1996, 56, fig. 9; 57 fig. 10. 


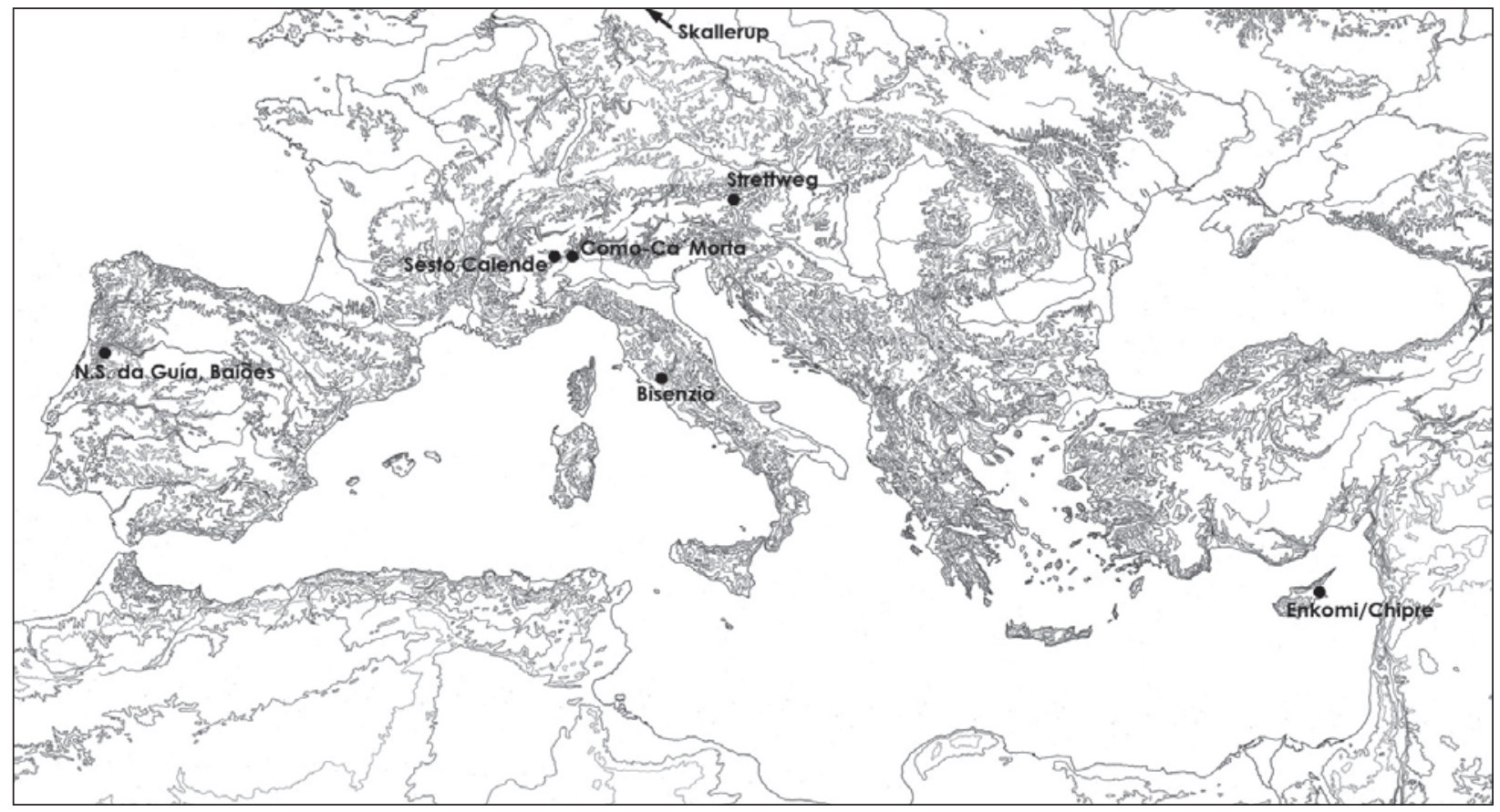

Figura 1: E. Puch, DAI Madrid

(fig. 1) $)^{8}$. Entre las más de 80 piezas encontradas figuran hachas de talón de distintos tipos, hoces tubulares, cuencos de bronce, puntas de lanza, asadores, brazaletes y ajorcas, una cuja, una fúrcula, un molde de fundición y fragmentos de varios carros con copa (fig. 2). Los tipos de objetos hallados se corresponden con los que se encuentran normalmente en los numerosísimos depósitos de esta época en Portugal': armas (lanzas), joyas (ajorcas y brazaletes), herramientas de trabajo (hachas y hoces), utensilios de culto (fúrculas y asadores).

En esa época, el castro de Baiões era conocido por su riqueza en hallazgos de objetos metálicos, entre otras razones, porque ya antes, en 1947 , habían aparecido en la ladera norte tres anillos de oro, con un peso de $1,559 \mathrm{~kg}$, durante la construcción de una vía pública. Philine Kalb comparó los anillos con las culturas nórdicas y del Danubio y los dató a mediados de la Edad del Bronce, es decir, a principios de la segunda mitad

8 Sobre la historia de la investigación v. Kalb 1978, 113; Silva - Silva - Lopes 1984, 73 y s.; Kalb 1993, 93-96.

9 Kalb 1978, 113; Kalb 1993, 92. El Tesoro se conserva actualmente en la Colección de la Universidad de Viseu. Mi agradecimiento al conservador del museo, J. L. Inês Vaz, que me facilitó la visita a la citada institución el 8 de agosto de 2009. Lamentablemente, no fue posible ver todas las piezas, porque algunas habían salido de la institución con distintos fines y el paradero de algunas de ellas era desconocido; v. al respecto Vilaça 2008, 131, nota 64. del II milenio a. C. ${ }^{10}$ Así pues, en este caso se trata también de un indicio de la existencia de contactos lejanos, lo que, por otro lado, no resulta sorprendente a la vista de las múltiples y variadas relaciones de la Edad del Bronce atlántica y las culturas de Europa Central ${ }^{11}$.

En la publicación del hallazgo por parte de Armando Coelho Ferreira da Silva y su colega de entonces (1984), el lugar aparece identificado como «depósito de fundidor» ${ }^{12}$, expresión que en la bibliografía ha pasado a denominarse «depósito». Esta denominación no es, sin embargo, correcta del todo y quizá resulte incluso equívoca, pues, en conjunto, las piezas halladas no datan exclusivamente de un único año de descubrimiento ni proceden solo del lugar del hallazgo del tesoro. La citada publicación incluye también material más antiguo, algunos objetos aislados que se recogieron en diversas partes del castro en el año 1971 o que, probablemente, fueron excavados sin autorización ${ }^{13}$, sin que en el

10 Kalb 1991, 190-192.

11 Kalb 1991, 191 y s.; cf., por ejemplo, los artículos sobre estos temas publicados en las actas del Congreso Jorge 1998.

12 Silva - Silva - Lopes 1984, 73-75.

13 Silva - Silva - Lopes 1984, 74; Kalb 1993, 93 y s.; Armbruster 2003, 145. 

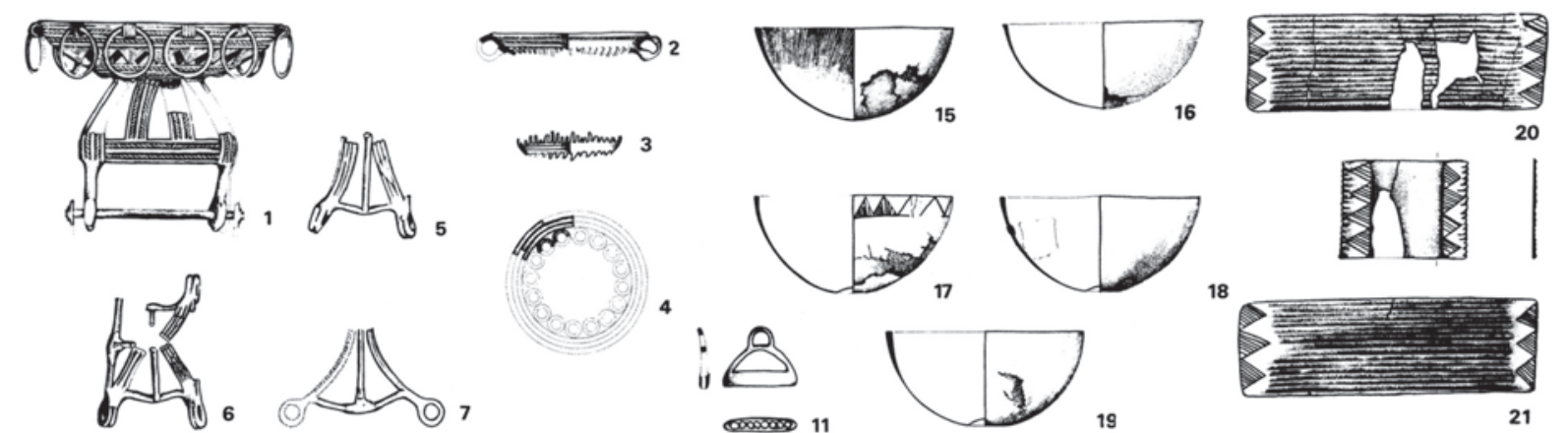

2usclyoumy 3
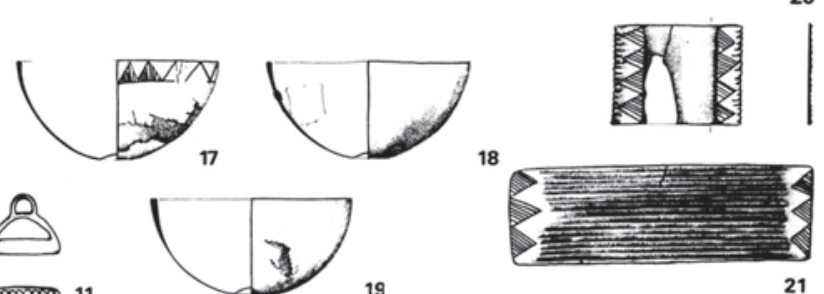

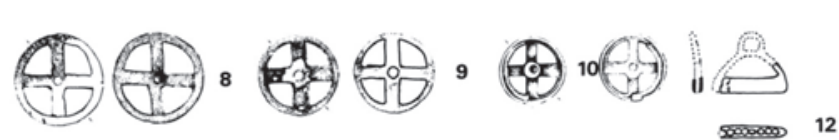

(Q) (.)

雷

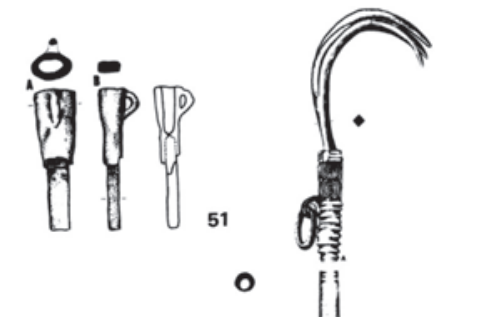

(?) :

(

(C)
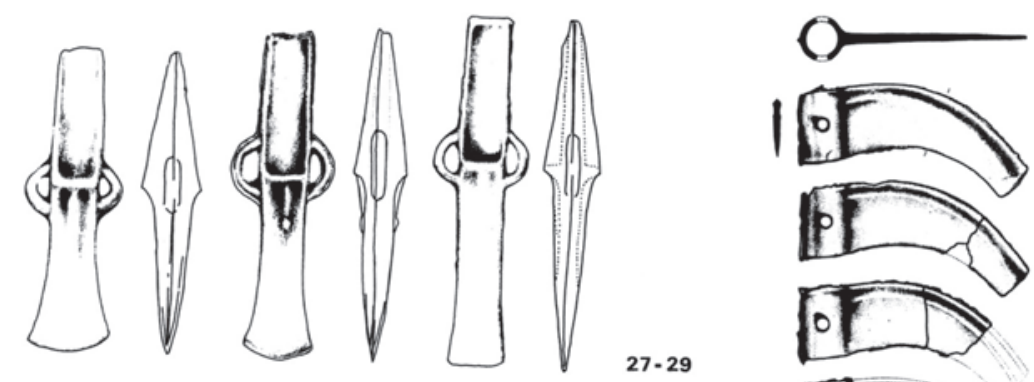

(क) 0

27-29

bi

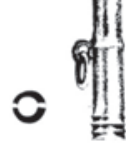
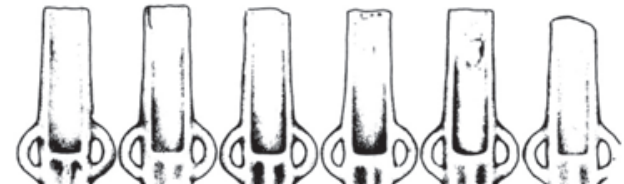

7

of 0

$\circ$

41

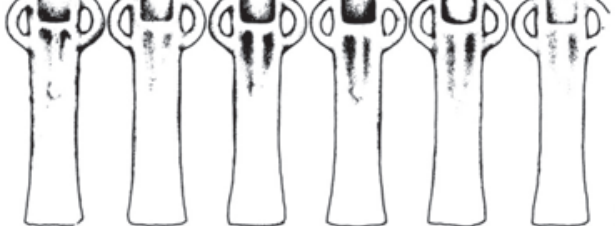

$30-35$
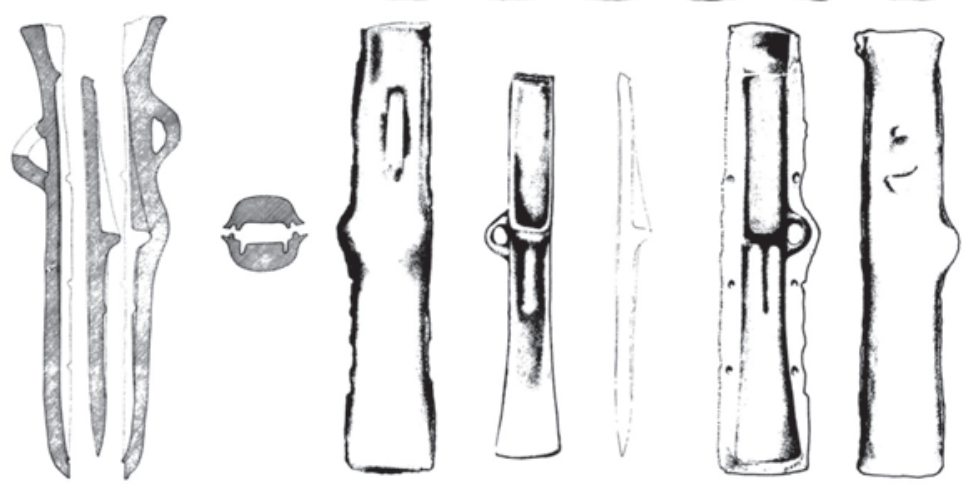

$36-38$
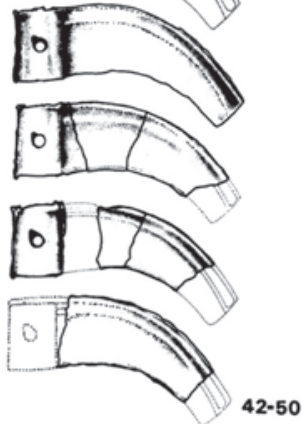

$\left[\begin{array}{ll}-1 \\ 0\end{array} \|_{52}\right.$

Figura 2: Ruiz-Gálvez 1993, 51 
texto o en las imágenes se aluda a esta circunstancia. De ahí, la sugerencia de un contexto unitario del hallazgo. Ante este trasfondo, resulta comprensible que se elaboraran otras hipótesis, basadas en la interpretación del hallazgo como restos de una herrería, es decir, al fin y al cabo, un depósito de chatarra de fundición, similar a los que se han encontrado en los castros vecinos de Cabeço do Crasto de São Romão y Outeiro dos Castelos de Beijós ${ }^{14}$. Como argumento a favor de esta opinión se aduce el estado de conservación de los objetos de metal hallados. Por una parte, muestran claras huellas de uso y, por ello, deben considerarse metal antiguo, pero, por otra, conservan todavía las habituales gotas de fundición y demás vestigios de haber sido recién fabricados, como atestigua también el molde de fundición conservado ${ }^{15}$. Esto explicaría que, en la citada publicación, el yacimiento se interprete como «depósito de fundidor». De otro lado, la misma publicación excluye categóricamente que el lugar desempeñara cualquier función de culto, sugerida quizá por la existencia de utensilios rituales, tales como la fúrcula o incluso el carro con copa, del mismo modo que niega cualquier criterio de selección en la agrupación de los componentes del hallazgo ${ }^{16}$. En este sentido, el lugar en sí no aporta ninguna justificación para adoptar la denominación de «carros votivos» ${ }^{17}$, que en ocasiones puede leerse en la bibliografía especializada. La problemática del conjunto del hallazgo, en cuanto depósito, no es el objeto central de este

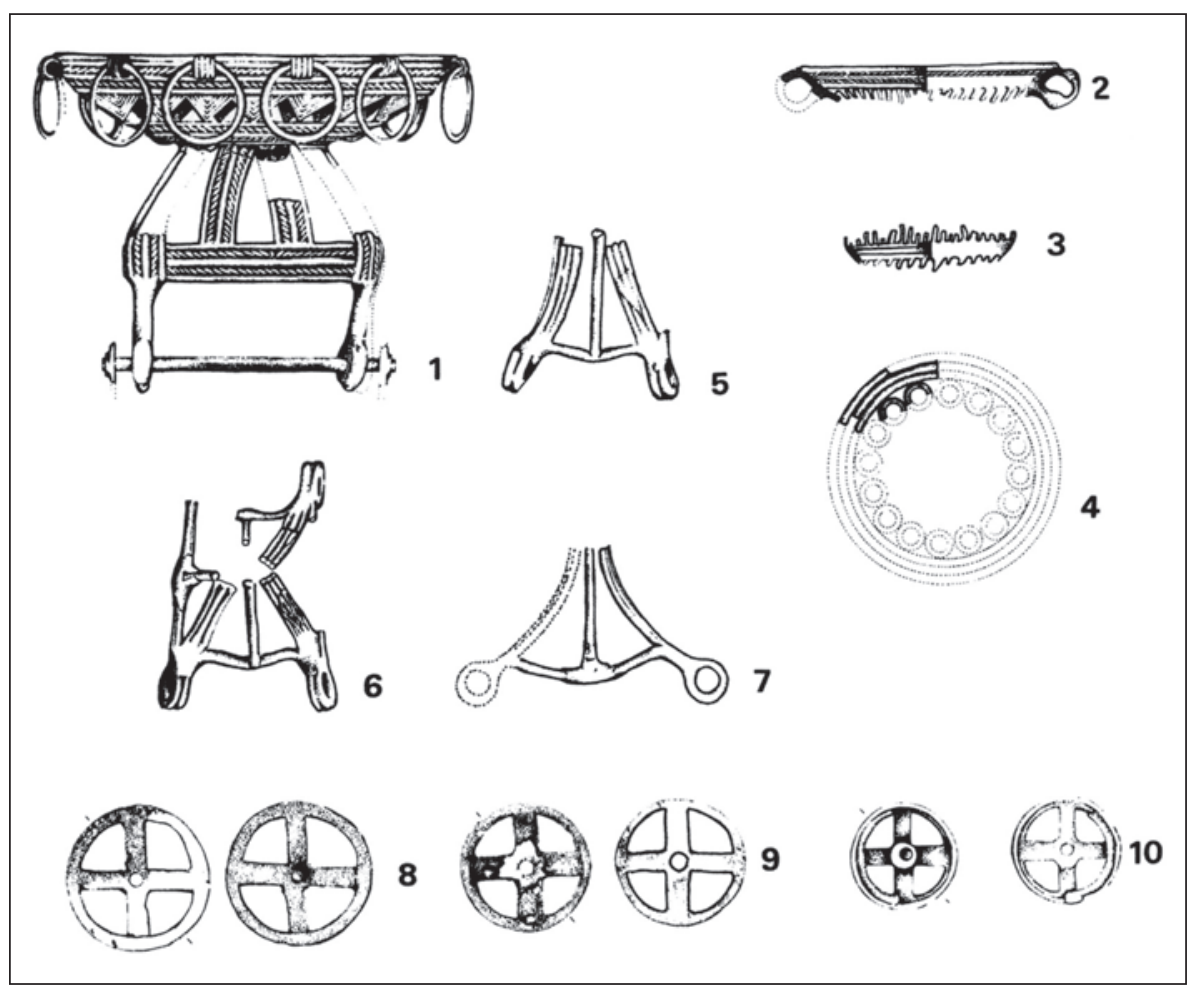

Figura 3: Ruiz-Gálvez 1993, 51 artículo, que se ocupa únicamente de los carros con copa $^{18}$.

\section{LOS TRES CARROS CON COPA DE BAIÕES}

Los fragmentos de los carros con copa (fig. 3, 1-10) son de bronce ${ }^{19} \mathrm{y}$, una vez ensambladas las piezas correspondientes, parecen indicar que se trata de, al menos, tres carros ${ }^{20}$. Esta cifra se deduce de los tres recipientes superiores, así como de las tres ruedas, cada una de ellas de distinto tamaño o diámetro. Desde el punto de vista de esta interpretación, no hay, en principio, ningún motivo para una lectio difficilior o, dicho de otro modo, que sustente la hipótesis de que las ruedas de distintos tamaños pertenecieran a un mismo carro. Hoy por hoy faltan puntos de referencia para atribuir con certeza las ruedas a uno de los carros. La base del recipiente del carro 2 no puede combinarse con el fragmento, muy parecido, de otra base que aquí se asigna al carro 3 , porque los perfiles 
curvados no encajan. Asimismo es posible que la pieza estuviera mal dibujada, lo que, sin embargo, no puede verificarse, ya que ha desaparecido ${ }^{21}$.

Carro de Baiões 1 (figs. 3, 1; 3, 9; 4): reconstruido casi por completo a partir de fragmentos por los restauradores del Museo de Conímbriga empleando la rueda de Baiões ${ }^{22}$. Este ejemplar tenía cuatro ruedas y un bastidor metálico rectangular casi cuadrado $(6,5 \times 5,5 \mathrm{~cm})$. Soportes verticales en forma de barra decorados con bandas trenzadas llegaban hasta el bastidor, doblándose entonces hacia el interior para sujetar la copa plana. En la parte inferior, los soportes acaban en ojales redondos y se unen al eje de la rueda, que queda fijo gracias a ellos. Falta uno de los dos ejes, así como partes de la rueda conservada, cuyo cubo, en cambio, se ha conservado. En total hay doce barras de soporte. La copa tiene forma de casquete esférico y consta de tres frisos. El superior y el inferior están decorados con cordones y el intermedio presenta un esquema calado. Dieciséis triángulos invertidos se alternan en zigzag con los espacios correspondientes a otros tantos triángulos dispuestos idealmente con el vérti- ce superior hacia arriba. Tanto en el friso superior como en el inferior, el segundo y el cuarto cordón adoptan la forma de cuerda trenzada; los demás son lisos. En el friso superior destaca la presencia de trece arandelas que cuelgan, a intervalos regulares, de otros tantos apliques dispuestos en la cara exterior de los cordones superiores. La copa presenta una abertura en el fondo.

Carro de Baiões 2 (figs. 3, 5-8; 5 a): bastidor de varas, ligeramente dobladas y dispuestas en diagonal, y láminas de metal, cuyos extremos exteriores terminan en ojales redondos ${ }^{23}$. Se han conservado tres extremos exteriores y entre los ojales hay barras de soporte con refuerzos salientes en el centro. Dado que las láminas presentan la misma secuencia de cordones lisos y cordones decorados en forma de cuerda trenzada, como se describe más arriba, en el carro 1, y más abajo, en el carro 3, el fragmento pertenece a un carro con copa. La prueba la aportan los ojales, en los que encajan los ejes, exactamente igual que en el carro 1. Es posible que este fragmento corresponda a una vasija de asas verticales, de las que una se ha conservado entera ${ }^{24}$. Hacia abajo sigue un

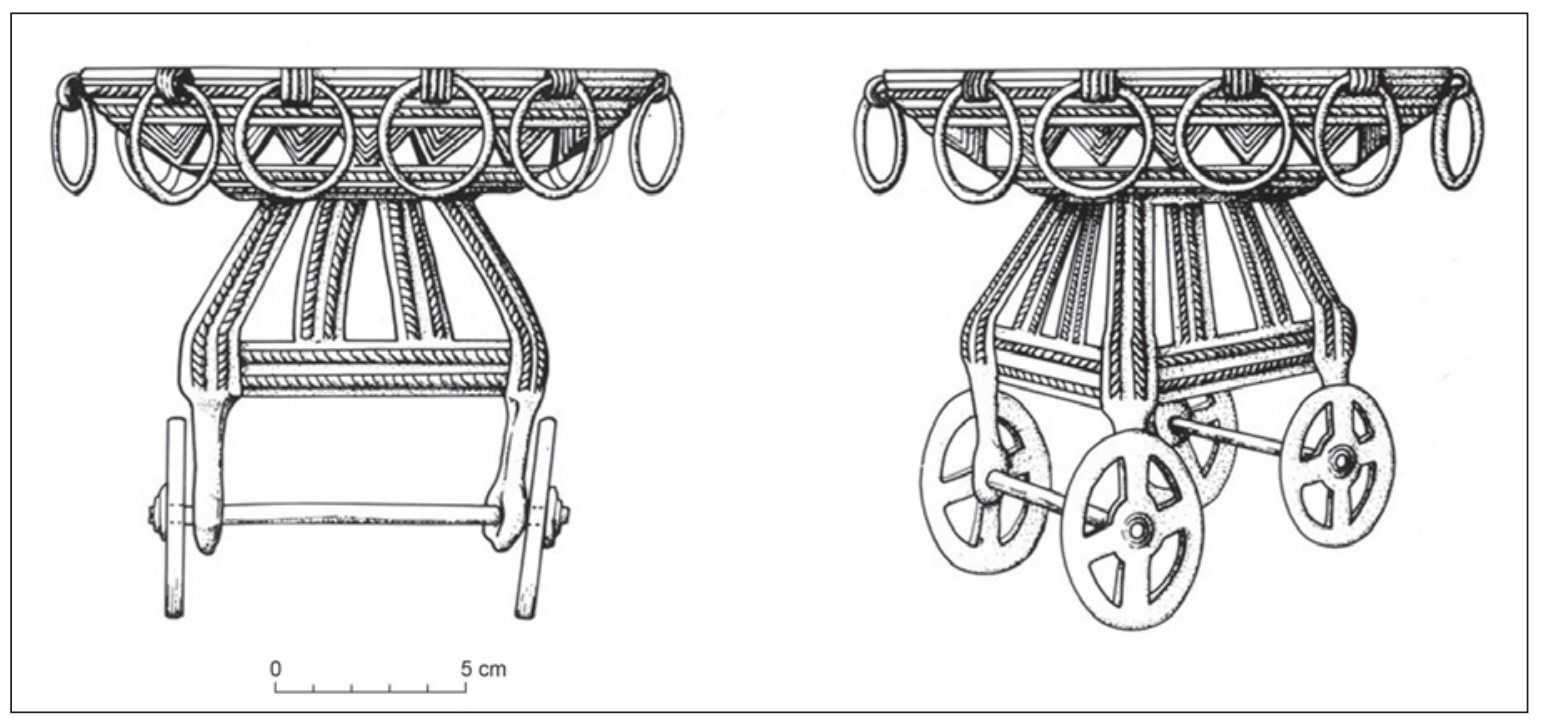

Figura 4: Silva-Gomes 1992

${ }^{19}$ Se analizó una muestra, v. Senna-Martínez 2000b, 71, Tab. I N. ${ }^{\circ}$ ME-097.

20 Silva-Gomes 1992, 72.

${ }^{21}$ Información suministrada amablemente por J. L. Inês Vaz/Viseu.

22 Silva - Silva - Lopes 1984, 85 Est. VIII 1 ab; Ulisses 1996, 186 N. ${ }^{\circ} 49$.

23 Silva - Silva - Lopes 1984, 86. - El bastidor pertenece sin duda alguna a un carro con copa. Delibes - FernándezManzano - Celis 1992/93, 421 consideraron también por un momento la posibilidad de que el bastidor pudiera engancharse a una yunta de bueyes.

24 En la publicación, el cuenco se reproduce en una ilustración, pero sin la correspondiente numeración. En Silva - Silva Lopes 1984 Est. VIII aparece a la derecha, junto al n.o 3 (rueda 1), y en el n..$^{\circ} 2$ a (reconstrucción del carro 2). La ilustración n.$^{\circ} 7$ muestra la vista en planta de la pieza. No obstante, el dibujo no tiene en cuenta el asa conservada, y los resaltes de las citadas costillas tampoco se han reconstruido como tales, sino como aros. 


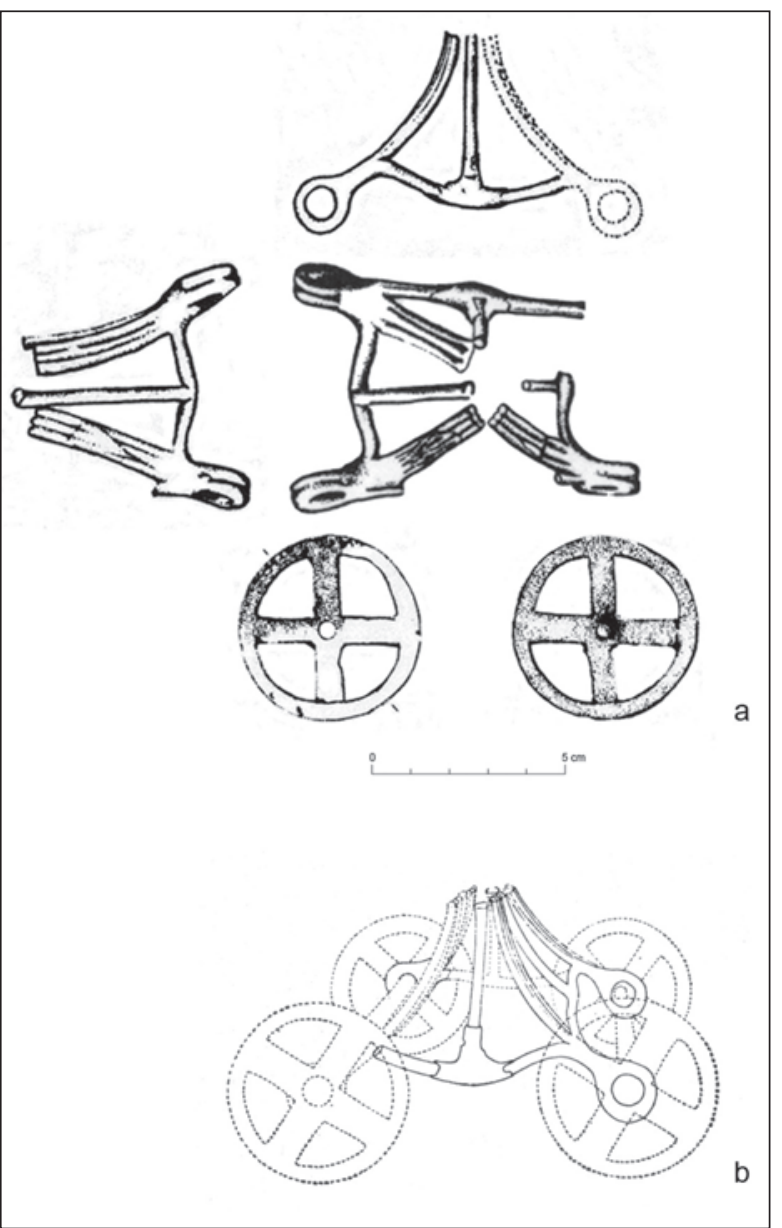

Figura 5: Silva, Iva - Silva - Lopes 1984 Est VIII 2.2 a.4.

friso calado, igual que en el carro 1. Su forma, en cambio, presenta largas brechas rectangulares dispuestas en diagonal a modo de costillas («cuenco de costillas»). Los excavadores lo han reconstruido empleando la rueda de Baiões 2 (fig. 5 b) ${ }^{25}$. Esta reconstrucción se amplía aquí (fig. 6).

Carro de Baiões 3 (fig. 7): la reconstrucción de un tercer carro es el resultado de dos consideraciones. La primera se basa en el hecho de que el diámetro de la tercera rueda es distinto de los otros dos, y la segunda está inspirada por el fragmento circular de un recipiente, que por su perfil no encaja en la copa del carro de Baiões 2, según el dibujo de la publicación original. El

25 Silva - Silva - Lopes 1984 Est. VIII 2 a.

26 Silva - Silva - Lopes 1984, 86.

27 Sobre el significado de los radios elegantes en comparación con otros más toscos, v. Pare 1987, 25.

28 La descripción y las ilustraciones de la primera publicación no parecen encajar. $\mathrm{O}$ la escala 1 : 3 indicada homogéneamente para todos los hallazgos reproducidos en la página no es correcta, o las remisiones a las ilustraciones no han sido insertadas en el texto en el lugar adecuado, pues

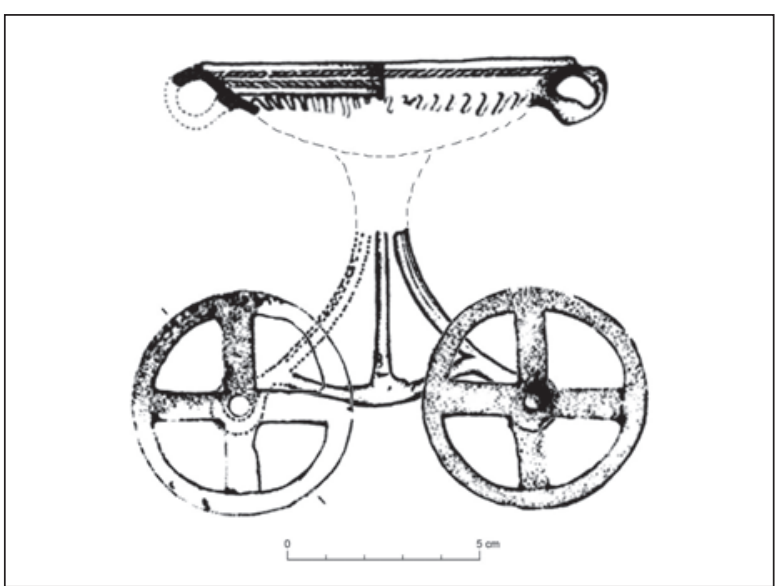

Figura 6: Silva - Silva - Lopes 1984 Est VIII 4 y Nr.

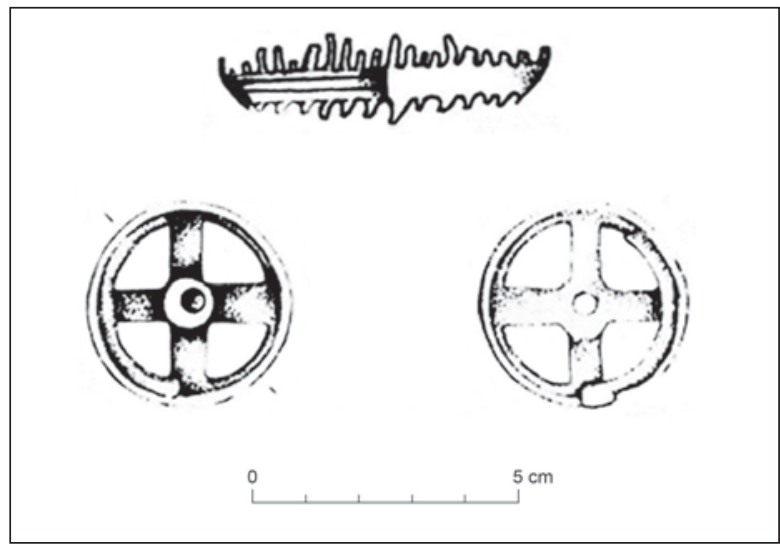

Figura 7: Silva - Silva - Lopes 1984 Est VIII 5. 6.

recipiente es liso por fuera, mientras que por dentro está decorado con cordones ${ }^{26}$. Hacia arriba y hacia abajo se han conservado restos lingüiformes, que sugieren la idea de un recipiente de costillas.

Las ruedas descritas forman también parte del depósito. Se trata, en su totalidad, de ruedas de $\operatorname{radios}^{27}$. Las descripciones que siguen a continuación se corresponden con las de la publicación ${ }^{28}$.

Rueda de Baiões 1 (figs. 2, 9; 3, 9). De cuatro $\operatorname{radios}^{29} \cdot 5,3 \mathrm{~cm}$ de diámetro. Recortada de una plancha de metal. Se observan huellas de cortes y marcas. Se conserva el eje.

la rueda que Silva - Silva - Lopes 1984, 86 Est. VIII, 3 describe como la más grande, en el dibujo correspondiente figura como Est. VIII, 4. La explicación más probable apunta a que no se ha mantenido la escala unitaria, ya que la descripción del eje conservado de la rueda 1 se corresponde con la ilustración correspondiente Est. VIII, 3. En cualquier caso, hoy en día no es posible verificarlo, porque, al parecer, las ruedas se han extraviado (v. más arriba con notas 9 y 21).

29 Silva - Silva - Lopes 1984, 86. 
Rueda de Baiões 2 (figs. 2, 8; 3, 8). De cuatro $\operatorname{radios}^{30} .4,8 \mathrm{~cm}$ de diámetro. Huellas de haber sido recién fabricada, tales como burbujas y rebabas de bronce. En la publicación se describe un pedacito de alambre metálico, encajado todavía en el agujero, que se supone un resto del eje. Sin embargo, también podría tratarse de un cubo de rueda engrosado, dado que en las otras dos ruedas se han conservado asimismo restos del eje, que por la parte exterior terminan, en cambio, a ras de la superficie.

Rueda de Baiões 3 (fig. 2, 10; 3, 10). De cuatro radios ${ }^{31} .3,9 \mathrm{~cm}$ de diámetro. En la parte interior, el mecanismo que sujeta el eje se compone de tres piezas encajadas una dentro de la otra: un anillo exterior, otro interior y un dispositivo para insertar el eje propiamente dicho.

\section{Historia de la investigación}

La citada publicación no pretende analizar la tipología de los carros con copa; el depósito en sí se equipara solamente con el hallazgo de otros tesoros comparables ${ }^{32}$. Colin Burgess (1991) atribuyó los carros a un entorno chipriota-levantino y propuso su datación en el siglo XI/X a. C. En las arandelas que en el carro 1 cuelgan de los apliques correspondientes, Burgess reconoce la influencia de copas atlánticas. En conjunto, considera que los carros son versiones locales de una idea procedente de Oriente ${ }^{33}$. Germán Delibes, Julio Fernández Manzano y Jesús Celis Sánchez (1992) describen los carros como orientalizantes y no dudan en datar el depósito a finales del siglo VIII a. C., basándose en la clasificación de los restantes hallazgos, en concreto, los ganchos para carne $^{34}$. Martín Almagro-Gorbea se refiere repetidamente al tesoro de Baiões. Data el depósito en el siglo X/IX a. C. y reconoce en los carros con copa una influencia mediterráneo-oriental-levantina: la decoración de cuerdas trenzadas apunta a Chipre; en su opinión, los carros se utilizaron originariamente en banquetes y proceden del entorno sirio-chipriota-sardo ${ }^{35}$. En 1993, André Coffyn

\footnotetext{
30 Silva - Silva - Lopes 1984, 87.

31 Silva - Silva - Lopes 1984, 87.

32 Silva - Silva - Lopes 1984, 95.

33 Burgess 1991, 38.

34 Delibes - Fernández - Celis 1992/93, 421 y s.

35 Almagro-Gorbea 1989, 283; Almagro-Gorbea 1992, 647; Almagro-Gorbea 1993, 86; Almagro-Gorbea 1998, 86; Almagro-Gorbea 2000, 714.

36 Coffyn - Sion 1993, 289.
}

y Hubert Sion establecieron por primera vez una relación con los carros con copa del centro y el norte de Europa, sin remitirse a los modelos chipriotas u orientales. Estos autores vieron en el carro de Bisenzio (Italia), perteneciente al siglo VIII/VII a. C. (fig. 8), el paralelismo más próximo con el carro con copa de Baiões 1. Basándose en la proximidad tipológica, deducen para esa época un vínculo entre Italia y el Occidente atlántico $^{36}$. Marisa Ruiz-Gálvez (1993) destaca los elementos mediterráneos del tesoro de Baiões, entre los que cuenta los carros con copa, que ella considera de inspiración e imitación chipriotas, como respuesta autóctona a un impulso procedente del entorno mediterráneo, y data el conjunto de los hallazgos entre los siglos X y VIII a. C. Sin embargo, al mismo tiempo toma también en consideración la posible importación del carro (como material de chatarra) ${ }^{37}$. Almagro y Ruiz-Gálvez incluyen los carros con copa de Baiões entre los hallazgos tempranos anteriores al comienzo de la colonización propiamente fenicia o, en su caso, mediterránea del siglo VIII/VII a. C., que ellos denominan fase precolonial, y a la que han dedicado gran cantidad de artículos ${ }^{38}$. Alfredo Mederos y Richard Harrison (1996) mencionan únicamente las características mediterráneas del carro 1 e incluyen los carros con copa de Baiões en una serie con ejemplares de Chipre, de donde extraen una datación temprana ${ }^{39}$. Bárbara Armbruster (2000) explica la parte técnica de la fabricación de los carros y reconoce paralelismos con los ejemplares chipriotas en el empleo del procedimiento de fundición a la cera, así como en la realización de los adornos mediante una construcción a base de alambres de cera. Ambas observaciones técnicas prueban un vínculo mediterráneo ${ }^{40}$. No obstante, en lo que atañe a la procedencia, se inclina por una fabricación in situ ${ }^{41}$. Raquel Vilaça $(2003,2006,2008)$ corrobora la datación de diversos hallazgos de Baiões mediante las comparaciones correspondientes y obtiene así un terminus ante quem en el siglo VIII a. C., que, sin embargo, solo puede ser provisional, ya que falta por realizar el estudio de la cerámica de

37 Ruiz-Gálvez 1993, 50-52; Ruiz-Gálvez 1995, 141; RuizGálvez 1998, 286. 300; Ruiz-Gálvez 2005, 263.

38 Las obras de estos dos autores citadas en la bibliografía contienen una bibliografía completa sobre este tema. Aubert 1992 incluye una recopilación de la información sobre los hallazgos de Italia.

39 Mederos - Harrison 1996, 250; Mederos 2009, 285.

40 Armbruster 2000, 183; Armbuster 2003, 151.

41 Armbruster 2000, 182; Armbruster 2003, 148. 

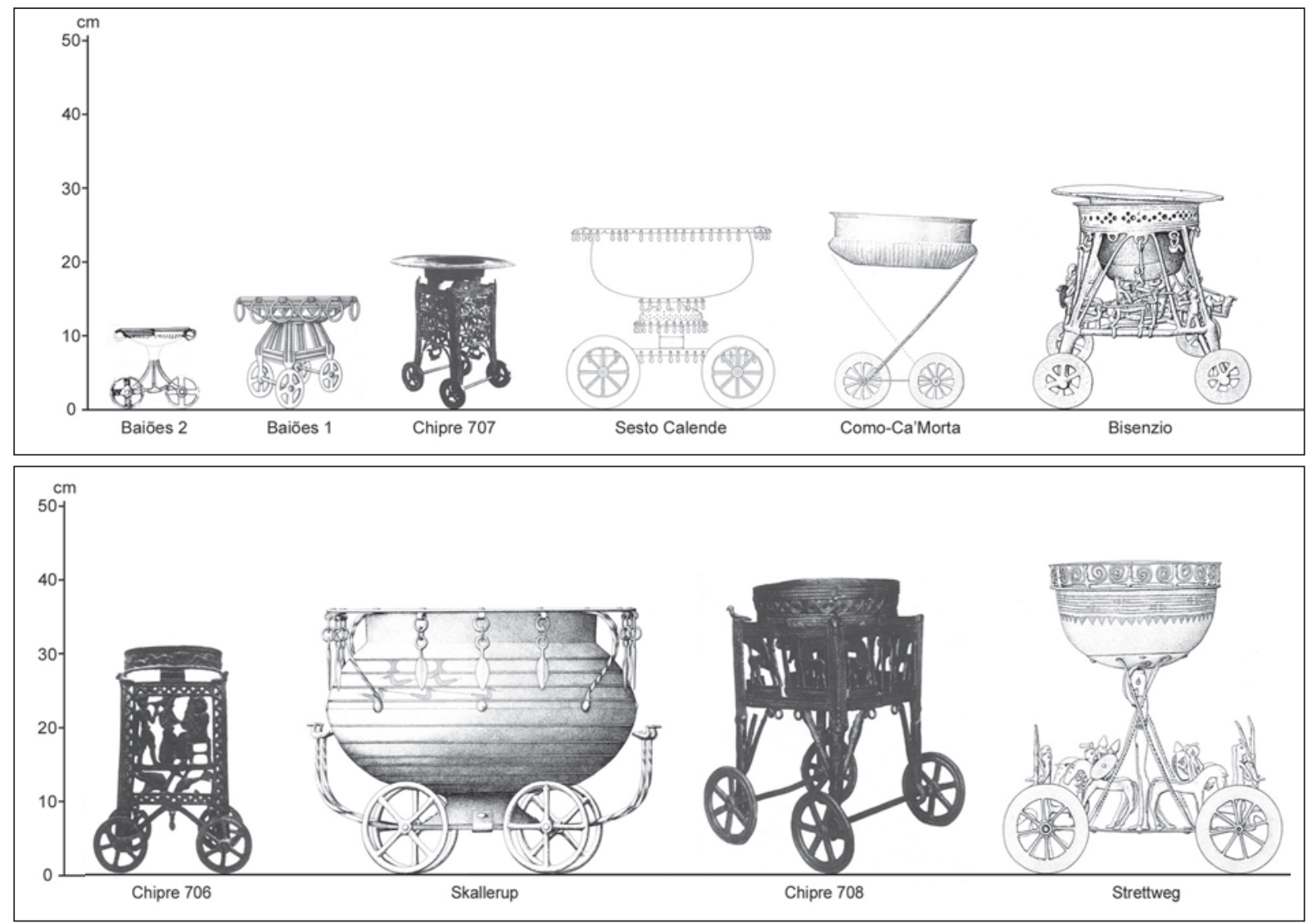

Figura 8: 10. 11: E. Puch, DAI Madrid.

las excavaciones del castro, que incluyen también material de la Edad del Hierro ${ }^{42}$. Virgilio Hipólito Correia $(2001,2009)$ interpreta los carros de Baiões como producto local que sigue el modelo fenicio, pero que, al quedar inacabados, se reutilizaron in situ. Este destino se manifiesta en forma de depósito de chatarra, como procede interpretar el tesoro de Baiões ${ }^{43}$. Por último, Fernando González de Canales (2004) considera los carros en cuestión un producto fenicio del siglo $\mathrm{X}$ a. C., que habría llegado a Baiões en el siglo VIII a. C. y Armada Rovira (2011) los tienen como productos locales fechables en época precolonial y claramente influenciados por la broncística sarda y chipriota (Armada-Rafel-Montero 2008) ${ }^{44}$.

La gran mayoría de los investigadores reconocen una influencia mediterránea. Según ellos, los carros con copa de Baiões atestiguan, a su vez, un

\footnotetext{
42 Vilaça 2008, 177. 208.

43 Correia 2001, 216; Correia 2009, 76.

44 González de Canales 2004, 249.

Armada-Rovira, 2011,31.

45 Silva - Gomes 1992, 72; Armada-Rafel-Montero 2008,472; Vilaça 2008, 112. 116; Correia 2009, 76.
}

vínculo lejano entre el Occidente hispánico central y el entorno del Mediterráneo o, más exactamente, del Mediterráneo oriental ${ }^{45}$. La relación con los carros con copa de Europa Central e Italia, establecida por Coffyn y Sion, solo la han admitido Yvone Pedro y Raquel Vilaça ${ }^{46}$.

\section{LOS CARROS CON COPA EN EL ENTORNO NÓRDICO Y EGEO-ORIENTAL}

Inspirándose en la entrada «Kultwagen» («carro votivo») del Reallexikon der Germanischen Altertumskunde, Markus Egg ha recopilado recientemente y ha descrito de nuevo las características esenciales, las agrupaciones tipológicas y las dataciones de los carros votivos nórdicos, señaladas ya en su publicación sobre el carro de Strettweg y en otras anteriores ${ }^{47}$. Del círculo de la cultura centroeuropea de los vasos de

46 Pedro 2000, 133: Europa Central; Vilaça 2008, 114: Italia.

47 Egg 1991, 195-201; Egg 1996, 29-36; Egg 2001, 464-468 con mapa de difusión 465 , fig. 50 . Aquí se puede prescindir de citar regularmente cada uno de los testimonios que se mencionan en las publicaciones más antiguas, ya que figuran en Egg 1996 y Egg 2001. 
embudo de la época en torno a los años 3000-2700 a. C. procede la representación más antigua de un carro de cuatro ruedas ${ }^{48}$. Según explica Egg, los carros votivos pertenecen al grupo de los carros con recipiente, extendidos desde Escandinavia a Grecia. Entre ellos, el grupo más grande y duradero lo constituyen los carros con copa, entre los que se encuentran las piezas de Baiões estudiadas en este artículo. Estos objetos pueden interpretarse como vasijas votivas o rituales y son típicos como ofrendas funerarias en la cultura de Hallstatt. Por esta razón, es lógico pensar que la vasija que se transportaba mediante un soporte con ruedas debió de desempeñar alguna función en el culto funerario. La estructura simétrica del carro, que a menudo impide distinguir la parte anterior de la posterior, es un rasgo característico. El carro sirve de soporte para la vasija que se coloca encima, por lo que está subordinado a ella. La vasija es, a su vez, un recipiente para líquidos $^{49} \mathrm{u}$ otra sustancia que desempeñaba la función primaria y, por tanto, resultaba imprescindible para el culto funerario. En las tumbas donde se han encontrado carros con copa entre los objetos del ajuar funerario a menudo existen también otros recipientes de bronce que probablemente desempeñaron asimismo un papel en el culto funerario como dispensador o receptáculo. La escasa capacidad de las vasijas que transportaban los carros con copa demuestra que no albergaban grandes cantidades de la sustancia de que se tratara. Puesto que las tumbas de la cultura de Hallstatt suelen contener un gran número de carros con copa, además de otros objetos funerarios habituales, tales como armas, los personajes enterrados serían probablemente varones. La excepción a esta regla es el carro de Bisenzio, que, al estar acompañado de una fusayola, sugiere que fue colocado en la tumba de una mujer ${ }^{50}$. Dado que casi todas estas tumbas contienen entre el ajuar funerario, además de carros con copa en miniatura, carros grandes, parece obvio que los carros con copa no sustituían a los carros grandes, sino que tenían un significado propio. El carro de Bisenzio (fig. 8), en Italia central, y el de Lucera, en Italia meridional, constituyen un tipo especial, pues tienen rasgos chipriotas, que se evidencian en la ornamentación de figuras y en las varillas decoradas con un dibujo grabado que, evidentemente, pretende simular cuerdas trenzadas. La ornamentación de figuras, las varillas grabadas y también los cuencos de costillas son elementos característicamente mediterráneos ${ }^{51}$.

Peter Schauer ha seguido la historia del carro de cuatro ruedas en las desarrolladas culturas egeo-orientales, cuyo comienzo sitúa en Mesopotamia hacia mediados del III milenio a. C. ${ }^{52}$ Los primeros vestigios son representaciones pintadas o modelos de carro. Con el hallazgo de dos carros grandes de cuatro ruedas en la tumba 789 de la necrópolis de Susa, se hace evidente el contexto funerario, en el que, en lo sucesivo, siempre aparecerán carros de cuatro ruedas. Hacia finales del III milenio a. C., se puede reconocer una primera difusión hacia Alaca Hüyük (Anatolia) y posteriormente también hacia los Kurganes del Cáucaso y Egipto, donde se inscribe claramente en los contactos de este último con el imperio hetita desde la dinastía XVIII. El carro hallado en la ciudad hetita de Acemhöyük (siglo XVIII a. C.) resulta interesante, entre otras razones, porque tipológicamente se pueden comparar con él algunos carros notablemente posteriores y de menor tamaño procedentes de Milaveã (Bohemia) y Skallerup (Dinamarca) (fig. 8). El estudio de estos ejemplares sugiere un vínculo -y también una dependencia- de las piezas centroeuropeas con el modelo hetita, que de este modo marca el comienzo de una serie tipológica.

El periodo del siglo XIII/XII a. C. tiene gran relevancia para nuestro planteamiento del problema en dos sentidos. En primer lugar, porque tanto en Chipre como en el centro y el norte de Europa se observa simultáneamente la creciente aparición de pequeños carros de bronce que portan vasijas (carros con copa). Desde la perspectiva del carro grande de Acemhöyük, se trata de un proceso de miniaturización, que se observa también en múltiples objetos utilizados como ofrendas votivas y ajuar funerario en tumbas y santuarios. En segundo lugar, es importante

\footnotetext{
48 Schauer 1987, 6 con fig. 5.

49 Análogamente, también los carros con copa del rei

51 Egg 1996, 31.
52 Schauer 1987, 1-23.

Salomón; v. Weippert 2006, 112 y s.

50 Recopilación en Egg 2001, 468.
} 
señalar que en el curso de ese proceso se produjeron cambios. El modelo grande no solo se ve reducido, sino que las miniaturas desempeñan, además, una función distinta. Por ejemplo, la copa del carro de Skallerup (Dinamarca) (siglos XIII-XI a. C.) no contenía líquido ni ninguna sustancia semejante, sino las cenizas del difunto (fig. 8), lo que, ciertamente, es un aspecto interesante. Su empleo en el contexto funerario está, por tanto, asegurado. Sin duda, podría abrirse un debate sobre el cambio funcional que se produce en Europa Central con la miniaturización, pero este no es el lugar apropiado para ello.

Tanto el formato pequeño como la función de portar vasijas son aspectos característicos de los ejemplares del Oriente Próximo y el Egeo ya desde su aparición a mediados del III milenio a. C. Entre todos ellos, las piezas de Chipre desempeñan un papel destacado. En esa isla, los carros con copa aparecen en tumbas desde el siglo XIII/XII a. C. ${ }^{53}$ En Grecia, los carros se documentan, en un contexto idéntico, desde la Edad del Hierro temprana, y también como representaciones de la ekphorá en la pintura de vasijas geométrica $^{54}$. La costumbre llega a Creta y desde aquí se extiende, posiblemente a través de Cerdeña $^{55}$, a Italia, tal como atestiguan los dos carros con copa de Bisenzio (fig. 8) y Lucera, desembocando finalmente en una producción local autóctona.

Mientras que los carros con copa del entorno centroeuropeo se localizan exclusivamente en el contexto funerario ${ }^{56}$, los de Oriente Próximo y el Egeo se encuentran también en santuarios como objetos utilizados en el culto ${ }^{57}$. No obstante, en la época de la gran colonización griega se observa una ampliación geográfica de los enterramientos en carros, que llega hasta Italia central, Etruria y

53 Matthäus 1985, 321: entre SC II C y SC III B, esto es, entre los siglos XIII y XI A. C. (tabla en Matthäus 1985, 11).

54 Ahlberg 1971, 184-196; al observar la ilustración en Ahlberg 1971, fig. 22 g (crátera de Nueva York) da la impresión de que, formalmente, podría tratarse de un carro con copa.

55 Lo Schiavo - Macnamara - Vagnetti 1985, 48-51.

56 Esta afirmación tiene una validez limitada debido a la ausencia conocida de santurarios y de los hallaszogs correspondientes.

57 En el caso de los ejemplares chipriotas, siempre se ha supuesto su utilización en el culto, aunque siempre se ha reconocido también que no existe un contexto para los hallazgos; resumen en Matthäus 1985, 320; Weippert 2006, 86. el sur de Hispania ${ }^{58}$, así como a Chipre y Azerbaiján (Persia). Este proceso transcurre paralelo a la difusión de técnicas altamente especializadas, como, por ejemplo, la toréutica. También en Europa Central se dejará notar en esta época la influencia correspondiente. En este sentido, tanto el florecimiento como el desarrollo de la tradición de los carros en el ámbito de las culturas de los Campos de Urnas de Europa Central, debidamente documentada en numerosos detalles, tales como la cabeza del radio en forma de embudo, se pueden relacionar fácilmente con la tradición mediterráneo-oriental de la época micénica tardía y postmicénica.

En resumen: en el periodo entre el Bronce Final y comienzos de la Edad del Hierro se pueden identificar dos ámbitos en los que los carros con copa no solo eran objetos autóctonos, sino que, además, conocieron épocas de apogeo. En primer lugar se trata del entorno del Oriente Próximo y el Egeo, con Chipre como punto central, donde los carros con copa aparecen tanto en tumbas como en santuarios, y, en segundo lugar, de Europa Central ${ }^{59}$, donde los carros se encuentran exclusivamente, al menos según se ha podido determinar, en contextos funerarios.

\section{LAS CARACTERÍSTICAS DE LOS CARROS CON COPA Y LA CLASIFICACIÓN TIPOLÓGICA DE LOS CARROS DE BAIÕES}

Las características de cada uno de los carros de los dos ámbitos mencionados más arriba han sido descritas en la bibliografía correspondiente por Woytowitsch, Matthäus, Pare, Egg, Kaul y Weippert ${ }^{60}$. A continuación se analizará la situación tipológica de los carros de Baiões atendiendo a dichas características. Como elemento de comparación se utilizarán, además de los tres

58 Se trata de dos tumbas (n. ${ }^{\circ} 17$ y 18 ) de la necrópolis de La Joya (Huelva), en las que en cada una de ellas había un coche (de dos ruedas) o partes del mismo. El hallazgo puede adscribirse a la transmisión de esa tradición egeo-oriental, que los navegantes fenicios llevaron hasta allí; v. Beba 2008, 40-64, con una bibliografía completa.

59 Aquí se utiliza el término >centroeuropeo<, que es más neutral que los más delimitados de >culturas de los Campos de Urnas < $\mathrm{o}>$ cultura de Hallstatt<, sobre todo porque los carros con copa se dan en ambas culturas; v. resumen en Egg 2001 y Kaul 2001.

60 Woytowitsch 1978, 56; Matthäus 1985, 316; Pare 1987, 2567; Egg 1996, 29-36; Egg 2001, 464; Kaul 2001, 473-475; Weippert 2006, 85 . 91-94. 
carros con copa de Baiões, otros ejemplares, que, de una manera u otra, han sido tratados hasta ahora por los autores en las publicaciones correspondientes. Visualmente aparecen reunidos en la fig. 8. El primer lugar lo ocupan los tres carros más conocidos -por ser también los mejor conservados- de Enkomi (Chipre) ${ }^{61}$ y porque, como se ha indicado al principio, la mayoría de los autores los relacionan, directa o indirectamente, con los carros de Baiões, lo que se manifiesta en connotaciones como chipriota, levantino, egeo u oriental $^{62}$. Asimismo, se ha incluido el carro de Bisenzio (Italia central) ${ }^{63}$, puesto que, según Coffyn y Sion, es el que muestra más coincidencias con los carros de Baiões ${ }^{64}$. A ellos se han añadido también el carro de Strettweg (Estiria), como representante más conocido de los carro de la cultura de Hallstatt ${ }^{65}$, el mencionado carro de Skallerup, como representante de la cultura de los Campos de Urnas y, por lo tanto, el más antiguo de los carros de Europa Central, y, finalmente, los carros lombardos de Sesto Calende y Como$\mathrm{Ca}{ }^{\prime}$ Morta $^{66}$. La inclusión de estos dos carros obedece a que son los ejemplares más próximos a los de Baiões en el sentido de que, a pesar de ser tipológicamente distintos, proceden de una misma zona, ya que los lugares donde se hallaron se encuentran muy cerca el uno del otro.

En la fig. 8, los carros aparecen ordenados por tamaño o, en su caso, altura. El conocido como Baiões 2 -el más pequeño $(11 \mathrm{~cm}$ de alto reconstruido)- figura al principio, y el carro de Strettweg -el más grande (42,3 cm de alto)- al final ${ }^{67}$.

\section{Características Chipriotas (Fig. 8)}

La característica esencial de los carros con copa chipriotas es la alta estructura cuadrado-rectangular, en forma de caja, que descansa sobre ruedas. De cada esquina de la estructura parte, a

61 Matthäus 1985, 316-320 Nr. 706. 707. 708. Tal como expone Weippert 2006, 91 y s., entretanto se han conocido seis ejemplares de carros con copa procedentes de Chipre.

62 v. más arriba el apartado dedicado a la historia de la investigación.

63 Woytowitsch 1978, 58-60 n. ${ }^{\circ} 127$ con bibliografía completa; Egg 1996, 30 fig. 20, 1.

64 Coffyn - Sion 1993, 289.

65 Egg 1996, 14-63; Egg 2001, 464.

66 Woytowitsch 1978, 61 n. ${ }^{\circ}$ 129; Egg 1996, 29 fig. 19. 20.

67 Weippert 2006, 96 señala que los carros con copa del rei Salomón tenían 3 metros de altura como mínimo. su vez, una barra vertical que la sujeta a las ruedas. El extremo inferior de las barras verticales termina en un ojal redondo, que acoge el eje de las ruedas. La caja está compuesta por láminas de bronce perforadas. Mediante la técnica del calado se reproducen diversos motivos, pero también figuras ordenadas en frisos y dispuestas, en parte, unas encima de otras. A la forma rectangular de la parte icónica que resulta de la posición elevada de la base se contrapone la disposición en frisos ${ }^{68}$. Las superficies de las láminas de bronce están decoradas con cordones, de los que unos son lisos y otros, trenzados. La copa propiamente dicha descansa sobre las barras de soporte de la estructura rectangular. Como la copa es redonda, los puntos de contacto con las barras se encuentran, respectivamente, en el centro de cada uno de los lados $^{69}$. En la vista esquematizada en planta, se observa un cuadrado (caja), en el que hay inscrito un círculo (recipiente) (fig. 9 a).

Los recipientes de costillas de los carros de Baiões 2 y 3 son un elemento mediterráneo. Como es sabido, en el ámbito occidental son típicos del norte de Etruria, pero también están extendidos en el área de influencia de la cultura de Hallstatt ${ }^{70}$.

\section{Características Centroeuropeas (Fig. 8)}

La característica esencial de los carros con copa de Europa Central es, por el contrario, la construcción dispuesta encima de un apoyo central asentado en el centro del cuadrado que delimitan las ruedas. El apoyo puede estar diseñado a modo de apoyo central único, como en los carros de Skallerup (Dinamarca) ${ }^{71}$ o de Sesto Calende

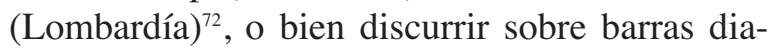
gonales, como en los citados ejemplos de Bisenzio o Strettweg. Las variantes pueden adscribirse a una preferencia regional, puesto que los

68 Compárense también los frisos de los carros con copa de la cueva de Zeus en el monte Ideon, en Creta, Rolley 1977, 119-129, cuyas barras interiores oblicuas desembocan en soluciones icónicas interesantes.

69 V. la descripción de carros con copa en el Antiguo Testamente en 1Kön 7, 27-39, citado en Weippert 2006, 7377 , con la historia de la investigación referente a la atribución de términos antiguos a los distintos compenentes del carro.

70 Frey 1980, 104-106 con fig. V. 105 (mapa de difusión); Egg 1996, 31.

71 Schauer 1987, 8 fig. 7.

72 Woytowitsch 1978, 61 n. ${ }^{\circ}$ 131; Egg 1996, 29 fig. 19, 1. 
carros con apoyo central están extendidos al norte de los Alpes y los que presentan apoyos en diagonal, al sur de la citada cordillera. En la zona de Alpes propiamente dicha aparecen ambas variantes una junto a la otra.

Los soportes diagonales parten de cada una de las cuatro esquinas y ascienden en oblicuo para actuar de portadores del recipiente, que descansa en los extremos superiores. Si se alargaran, se encontrarían en un punto situado sobre el centro del bastidor. En la vista esquematizada en planta se observa un cuadrado (caja), de cuyas esquinas se proyectan sendas diagonales hacia el centro para soportar allí la base circular del recipiente ${ }^{73}$ (fig. 9 b). Para impedir que, dado el caso, las diagonales resulten demasiado pronunciadas, y probablemente también para aportar más estabilidad a la construcción, en ocasiones aparecen cruzadas, como en los carros de Strettweg y Como$\mathrm{Ca}^{\prime} \mathrm{Morta}^{74}$, donde los soportes no se asientan en la rueda más cercana, sino en la más alejada, entrecruzándose por tanto en los laterales del carro. Curiosamente, el punto de partida de los soportes del carro de Strettweg no se encuentra en la propia rueda, sino en el bastidor, lo que indica que no se integraron en la estructura del carro con una intención funcional. Debido a datación del carro, quizá se trate de una forma tardía, en la que la mencionada relación funcional entre las barras de soporte y las ruedas hubiera desaparecido.

Las barras de soporte están, en general, torsionadas. En las barras torsionadas, Egg ve, probablemente con razón, la adopción de un modelo egeo $^{75}$. Tanto los elementos colgantes sonoros

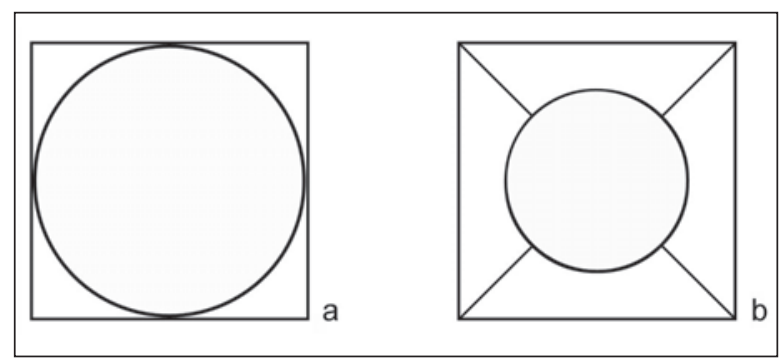

Figura 9: E. Puch, DAI Madrid: Vilaça 1999, 158

\footnotetext{
73 Sugestiva descripción del carro de Bisenzio en Woytowitsch 1978 Tav. s. 24 q.

74 Egg 1996, 29 fig. 19, 2.

75 Egg 1996, 31.

76 Guggisberg 1996, 186. El término >Klappergehänge< (colgantes sonoros) se ha introducido aquí en analogía con el
}

(Klappergehänge) como las láminas metálicas que hacen ruido (Klapperblech) son característicos de los carros centroeuropeos ${ }^{76}$, al igual que los cubos de rueda engrosados, que se observan habitualmente en carros con copa de las culturas de los Campos de Urnas, de la Edad del Hierro temprana y de Hallstatt.

\section{Sobre la tipología de los CARRos CON COPA DE BAIÕES}

En la tabla que sigue a continuación, las características mencionadas se clasifican en cuatro grupos según su adscripción geográfico-cultural, y los carros con copa se ordenan debidamente. Como es natural, la tabla tiene carácter aleatorio, ya que solo se ha incluido la pequeña selección de ejemplares mencionada con anterioridad. No obstante, las regiones descritas están suficientemente representadas en la selección, proporcionando así parámetros de comparación apropiados para los carros de Baiões objeto de estudio. Estos carros proceden de un contexto hispánico o, mejor dicho, hispánico-occidental, es decir, de un contexto marcado en aquella época, de una parte, por las tradiciones indoeuropeas y atlánticas arraigadas y, de otra, por las influencias mediterráneas que llegaron a tierra firme a través de los navegantes fenicios.

El grupo 1 destaca por las características chipriota-orientales descritas, que solo se pueden observar aquí. El grupo 2 muestra, por el contrario, rasgos exclusivamente centroeuropeos. En los carros con copa de los grupos 3 y 4 aparecen mezcladas características de ambas regiones. Los carros de Bisenzio y Baiões 1, por ejemplo, poseen barras de soporte verticales que ascienden desde los ejes de las ruedas y soportan el bastidor, del que arrancan las barras diagonales. Mientras que en Baiões 1, el bastidor tiene forma de caja cuadrado-rectangular, como en los carros chipriotas, en el carro de Bisenzio las barras están ya colocadas en posición oblicua y conectan con las barras diagonales. El hecho de que las primeras sean

usual >Klapperblech (láminas sonoras). La creación del término ha sido necesaria, porque la forma de los aros que en Baiões 1 cuelgan del borde de la copa difieren de las láminas. La forma redondeada, el aro para colgar y la función del elemento sonoro eran, sin embargo, iguales. 
más gruesas y las segundas más finas probablemente indique que tenían fines y significados distintos. Tipológicamente, Baiões 1 se encuentra más próximo a los carros chipriotas, y Bisenzio, más alejado. Una afinidad parecida entre ambos carros es el empleo de cordones como decoración de la copa ${ }^{77}$.

En los tres carros de Baiões llama la atención el hecho de que presenten características de ambas regiones en distinta medida. Baiões 1 ocupa una posición especial: el carro posee casi en su totalidad los rasgos mencionados, es decir, tanto los chipriota-orientales como los centroeuropeos. En la lista de las características solo falta, en principio, la ornamentación de las figuras. Asimismo, en lugar de las varillas torsionadas que quizá cabría esperar, presenta el diseño ornamental a base de cordones lisos y cordones trenzados, es decir, en cierto modo, la decoración chipriotaoriental descrita anteriormente. El empleo de ambos tipos de elementos en el carro de Baiões 1 revela gran habilidad y está muy logrado formalmente. En este sentido, este carro con copa encarna un vínculo convincente entre ambos grupos de características regionales.

Muy distinto desde el punto de vista tipológico se comporta Baiões 2, pues su estructura y construcción muestran en el apoyo central el rasgo centroeuropeo determinante. Como características chipriota-orientales solo cabe mencionar el calado y la copa con costillas.

El carro de Baiões 3 resulta problemático porque no está comprobada la correspondencia entre la rueda y la copa. Si pertenecieran al mismo ejemplar, la decoración de costillas de la copa constituiría un elemento mediterráneo, mientras que el cubo engrosado de la rueda 3 sería centroeuropeo.

En conjunto, los carros de Baiões arrojan un cuadro divergente, ya que en ellos se dan ambas formas de construcción, radicalmente diferentes: la versión chipriota-oriental combinada con la centroeuropea en el carro 1, y la centroeuropea en

77 Todas estas coincidencias explican la presunción -no desarrollada- de Coffyn - Sion 1993, 289 acerca del parentesco entre ambos carros.

78 v. observación anterior con nota 7.

79 v. nota 19

80 Vilaça 1997, 140; Senna-Martínez - Araújo - Valério Peixoto 2004, 328; Valério - Araújo - Senna-Martínez - el carro 2. El carro 3 no se puede evaluar realmente atendiendo a esos factores. A pesar de las diferencias tipológicas, sí se puede destacar ya en este momento la llamativa afinidad que existe entre los carros de Baiões. Tanto el tamaño y la construcción a base de delgados soportes metálicos como el formato y el tipo de recipiente utilizado a modo de copa son de factura muy similar $\mathrm{y}$ confieren a todos los ejemplares un rasgo común, un aire de familia.

\section{Clasificación}

\section{VALORACIÓN}

El hallazgo de los carros con copa sorprende básicamente por dos razones: por una parte, por su localización en Baiões, localidad situada en el centro de Portugal, y por tratarse de tres carros como mínimo $\mathrm{y}$, por otra, porque es único entre los hallazgos de la época no solo a nivel local y regional, sino también en toda la Península Ibérica en el mismo periodo y porque su exclusividad se mantuvo durante mucho tiempo. Los demás hallazgos de carros en miniatura en la Península, que encarnan diversos tipos, se datan en parte en una época notablemente posterior, en los siglos VI y V a. C. e incluso hasta el II/I a. C.; además, no son carros con copa ${ }^{78}$.

\section{Procedencia}

Para determinar la procedencia, se debe recurrir en primer lugar a los análisis del metal, a los que, entretanto, han sido sometidas muchas piezas del depósito y, en parte, también los car$\operatorname{ros}^{79}$. Casi todas las piezas son de bronce, obtenido regularmente mediante aleaciones de cobre y estaño $(\mathrm{Cu}, \mathrm{Sn})^{80}$, y su calidad es buena ${ }^{81}$. El contenido de estaño es muy alto, lo que, por una parte, se atribuye a la corrosión ${ }^{82}$, pero, por otra, tampoco debe sorprender ${ }^{83}$, dado que en la región (Serra da Estrela) existen yacimientos importantes de estas características, que fueron explotados en la Antigüedad ${ }^{84}$. Quizá llame la

Inês Vaz 2006, 314; Vilaça 2008, 117

81 La buena calidad es una característica metalúrgica de la región, v. Vilaça 1997, 142.

82 Valério - Araújo - Senna-Martínez - Inês Vaz 2006, 308.

83 Vilaça 1997, 142 señala que un alto contenido de estaño en los bronces más elaborados de la región es normal.

84 Senna-Martínez 1994, 223 con bibliografía antigua. 
atención el hecho de que en la aleación falte el plomo, que está presente -y además en una concentración elevada- en los bronces del noroeste hispánico y, por ello, constituye un rasgo distintivo de esa región y de esa época $(\mathrm{Cu}, \mathrm{Sn}, \mathrm{Pb})^{85}$. Por el contrario, las aleaciones binarias de cobre y estaño son un indicador general del Occidente hispánico, pero también de la procedencia mediterránea, en este caso, sarda ${ }^{86}$. La frontera entre ambas regiones queda claramente marcada por el río Duero ${ }^{87}$. A modo de resumen puede decirse que, lamentablemente, los análisis del metal no han dado hasta ahora ningún resultado inequívoco acerca de la procedencia de las piezas ${ }^{8}$.

Entre los autores que han estudiado el depósito $y$, en especial, los carros con copa, no se ha impuesto ninguna opinión sobre la determinación de la procedencia, como se desprende del capítulo precedente dedicado a la historia de la investigación. A los defensores de un origen local -Burgess, Armbruster, Correia, Armada y Rovira, Armada-Rafel-Montero- se oponen los partidarios de uno foráneo, en concreto, del Mediterráneo oriental; entre ellos figuran Almagro-Gorbea, González Ruibal (2007) y Fernández de Canales. Otros no se decantan por ninguna opción: Delibes, Fernández y Celis, Mederos y Harrison, Vilaça. Ruiz-Gálvez defiende unas veces esta opinión y otras, aquella, y no es capaz de decidirse entre ambos lugares de procedencia. Esta autora ha formulado la propuesta de solución quizá más extravagante, según la cual, debido al estado fragmentario de los carros con copa, se trataría de chatarra y, como tal, es decir, por su material y peso, habría sido importada desde el Mediterráneo oriental al Occidente hispánico ${ }^{89}$. Vilaça se ha posicionado al respecto y ha indicado acertadamente que no se corresponde con la lógica del comercio antiguo que se importara material en una región, en este caso, la Lusitania central, que es famosa por exportar precisamente dicho material, en este caso, bronce. De hecho, los hallazgos considerados importaciones del Occidente atlántico al ámbito mediterráneo son casi exclusivamente bronces ${ }^{90}$. Una serie

85 Vilaça 1997, 129. 141; Senna-Martínez - Araújo - Valério Peixoto 2004, 328; Valério - Araújo - Senna-Martínez Inês Vaz 2006.

86 Rovira 1995, 35-48. 55.

87 Vilaça 1997, 141.

88 Resumen en Vilaça 2008, 117.

89 Ruiz-Gálvez 1998, 286. 300; en esto le ha seguido Senna- de razones técnicas se opone, además, a la explicación como chatarra, como es el caso de reparaciones ejecutadas con esmero en ruedas recién fundidas o en las copas. Tampoco faltan razones de carácter práctico, como la cuestión de por qué el material hallado no fue prensado a fin de ahorrar espacio en el transporte, entre otras ${ }^{91}$.

En el debate acerca de la procedencia de los carros con copa merece recordarse ahora un argumento nuevo, que se ha denominado anteriormente «aire de familia $»^{92}$. Esta expresión describe la llamativa semejanza que caracteriza los tres carros de Baiões, a pesar de que sean tipológicamente distintos, y se pone de manifiesto tanto en el tamaño, en la construcción a base de estrechos soportes metálicos en forma de barras o varas delgadas y en el (pequeño) formato (cf. fig. 8) como en el empleo de recipientes de costillas a modo de copa, similares en su factura, $y$, finalmente, en un cierto carácter minimalista, que relaciona todos los carros entre sí. Este argumento debe interpretarse en el sentido de que los carros no tienen distinta procedencia, sino una procedencia común. Si se pudiera determinar la procedencia de un ejemplar, a los otros dos se les podría asignar la misma. En el panorama de los demás carros con copa (cf. fig. 8), los rasgos descritos indican que los ejemplares de Baiões ocupan una posición única, que los caracteriza. La pieza con un parecido mayor es quizá el carro de Como Ca'Morta, que, no obstante, se conserva sólo de forma fragmentaria.

\section{DATACIÓN}

La datación de los carros con copa se ha llevado a cabo mediante la nacionalización de los hallazgos, utilizando para ello las dataciones individuales de los componentes de la totalidad del tesoro, que han sido descritos en detalle en las publicaciones correspondientes. A modo representativo, cabe mencionar aquí la fúrcula, que, por la ornamentación del mango, encuentra su paralelo más próximo en un ejemplar del siglo VIII a. C. procedente de Dunaverney (Irlanda) ${ }^{93}$. Análogamente, desde el descubrimiento del tesoro

\footnotetext{
Martínez 2000a, 134, quien anterirmente había defendido otra opinión, Senna-Martínez 1994, 225 y s.

90 Vilaça 2008, 122 y s.

91 Vilaça 2008, 131.

92 V. el apartado sobre la tipología de los carros con copa de Baiões.

93 Delibes - Fernández-Manzano - Celis 1992/93, 421.
} 
hasta la actualidad, la bibliografía especializada sitúa en general la datación hacia finales del siglo VIII a. C. ${ }^{94}$ No obstante, la existencia de cerámica de la Edad del Hierro probablemente rebaje la datación del período de utilización del castro ${ }^{95}$, lo que, evidentemente, tendría consecuencias para la datación del así llamado depósito, ya que, al parecer, solo hay un único horizonte de utilización ${ }^{96}$, como reconoció Kalb. En efecto, los hallazgos de metal y cerámica quedaron sepultados en la misma época ${ }^{97}$. La verificación de las dataciones en cuestión, precisamente también en el contexto de las cinco dataciones disponibles con carbono 14, que transmiten una fecha entre los siglos X y VIII a. C., se considera urgente y necesaria ${ }^{98}$. Sin embargo, para el «depósito» que aquí interesa y especialmente para los carros con copa, las dataciones con carbono 14 no aportan nada ${ }^{99}$. Con la mirada puesta en las investigaciones pendientes de la cerámica de la Edad del Hierro y en lo que respecta a los carros de Baiões, puede decidirse sine ira et studio que una fecha algo más tardía se correspondería mejor con los ejemplares del grupo 3 procedentes de Bisenzio, Strettweg y Como Ca'Morta, tipológicamente cercanos, que se datan, respectivamente, en el siglo VIII/VII a. C., hacia el año 600 a. C., y en el siglo VII a. C. ${ }^{100}$ Esta época se considera el periodo de auge de los carros con copa ${ }^{101}$.

En el estado actual de las dataciones, el carro de Baiões 1, con una fecha de finales del siglo VIII a. C., sería claramente el más antiguo de Europa en esta serie, lo que no cuadraría bien con la expansión de los carros con copa, que gozan de su mayor densidad en Europa Central a ambos lados de los Alpes, mientras que Baiões, como se ha indicado, constituye el único hallazgo en la Península Ibérica.

Algo parecido se puede aplicar a Baiões 2. Con una datación en el siglo VIII a. C., este carro sería más antiguo que el ejemplar con el que se compara, esto es, el de Sesto Calende, perteneciente al siglo VII a. C. ${ }^{102}$.

94 Kalb 1978, 122-126; Delibes - Fernández-Manzano - Celis 1992/93, 421 y s.; Coffyn - Sion 1993, 289; Ulisses 1996, 186 n. . 49; González de Canales 2004, 249.

95 Kalb 1978, 122-126; Vilaça 2008, 132. 177. 208, v. arriba nota 42.

96 Silva 1979, 528; Vilaça 2008, 133.

97 Kalb 1978, 122.

98 Vilaça 2008, 132-134.

99 Vilaça 2008, 133

100 Resumen en Woytowitsch 1978, 60: siglo VIII/VII a. C. (Bisenzio). 61: siglo VII a. C. (Como Ca'Morta); Egg
Las observaciones y comparaciones tipológicas precedentes con los carros de Bisenzio, Strettweg y Como Ca'Morta confirman, por tanto, la datación convencional de los carros de Baiões. Sin embargo, hoy por hoy, parece indicado situarla un poco más tarde, quizá en el siglo VII a. C.

Las dataciones divergentes en la bibliografía de los carros con copa de Baiões tienden en general a una fecha más temprana. Estas propuestas quizá deban contemplarse en el contexto de una extendida tendencia hispana en favor de dataciones altas ${ }^{103}$.

\section{Clasificación histórico-CUltural}

\section{Clasificación anterior}

Durante mucho tiempo, de los tres carros con copa en cuestión, la investigación ha tenido en cuenta solamente el carro de Baiões 1, tal como se ha indicado anteriormente. Entretanto e independientemente de las distintas y sin duda problemáticas adscripciones geográficas - «chipriota- mediterráneo-oriental» o también «itálica»-, la bibliografía ha elevado el carro, y con él tácitamente también los otros dos, a la categoría de testimonio principal de la influencia mediterránea en el oeste de la Península $^{104}$. Resulta comprensible que Baiões 3 no haya sido objeto de comentarios, puesto que cualquier reconstrucción sería siempre especulativa debido a la ausencia de muchos componentes. En el caso de Baiões 2, en cambio, los arqueólogos reconstruyeron correctamente el bastidor. De ahí que pueda adscribirse directamente, como hemos visto (tab. 1), al grupo de carros centroeuropeos, puesto que posee la estructura característica.

\section{NUEVA CLASIFICACIÓN}

En el panorama general, el yacimiento de Baiões destaca en cuanto a los hallazgos de carros por el hecho de que las piezas presentan, en distintos grados, tanto las características chipriota-

1996, 245: hacia el año 600 a. C. (Strettweg).

${ }^{101}$ Guggisberg 1996, 187.

102 Resumen en Woytowitsch 1978, 52.61.

103 Siglo XII/XI. A. C. Mederos - Harrison 1996, 239. - Siglo XI/X a. C.: Burgess 1991, 38. - Siglo X/IX a.C.: AlmagroGorbea 1989, 283; Almagro-Gorbea 1992, 647; AlmagroGorbea 1993, 86; Almagro-Gorbea 1998, 86; AlmagroGorbea 2000, 714. - Siglos X-VIII a. C.: Ruiz-Gálvez 1993, 50. - Precolonial: Armada-Rovira 2011,31.

${ }^{104}$ V. apartado sobre la historia de la investigación con nota 45. 
orientales como las centroeuropeas. Estas últimas son tan importantes como nuevas, pues hasta ahora no estaban representadas en el concierto de influencias externas en el oeste central de la Península Ibérica. Aunque ciertamente se conocen bien influencias de diversa procedencia en la región, hasta ahora hacían referencia, a gran escala, a las influencias mediterránea y atlántica y, a pequeña escala, a la celta, celtibérica e ibérica ${ }^{105}$. La novedad consiste en analizar esas diversas influencias en un grupo monumental único, como es el de los carros con copa. El único paralelo directo se sitúa en el área meridional de los Alpes, donde, por ejemplo, los citados carros con copa de Sesto Calende y Como Ca'Morta pertenecen también a grupos distintos (tabla 1), aunque los lugares donde se hallaron se encuentran muy próximos entre sí (fig. 8). En concreto, se trata del entorno de la cultura de los Campos de Urnas y Hallstatt, respectivamente.

\section{Relaciones entre el área de los Alpes y la Península Ibérica y a la inversa}

Las relaciones entre el área de los Alpes y la Península Ibérica son escasas y se limitan al noreste hispánico. Por ello, las costumbres funerarias típicas de la cultura de los Campos de Urnas y sus hallazgos se concentran en el noreste de la Península Ibérica ${ }^{106}$. Es precisamente en el área del Ampurdán donde están más densamente representadas las hebillas de cinturón con placa de gancho rómbica o romboidal, cuyo origen es, al parecer, frigio o griego, y que en el siglo VI a. C. se utilizaban también tanto en la zona de Hallstatt como en el este y suroeste de Hispania $^{107}$, pero no en el oeste hispánico. Tan solo los mapas de expansión de las espadas de lengua de carpa muestran una dispersión que abarca tanto el entorno de los Alpes como la Hispania occidental ${ }^{108}$. Como hallazgo único especial cabe mencionar una espada de La Téne, que se encontró en Cachouça ${ }^{109}$. Dos fíbulas itá- licas halladas en el castro de Pirreitas, junto a la localidad de Alcobaça, en el centro de Portugal, pertenecientes claramente al siglo IX a. C. ${ }^{110}$, ofrecen una referencia concreta a Italia. En este contexto tampoco deben pasarse por alto las estatuas de guerreros que en el siglo VI/V a. C. aparecen extendidas tanto en Italia y en el entorno de la cultura de Hallstatt como, en época posterior, en el noroeste hispánico. En el contexto hispánico hay, como mínimo 32 ejemplares ${ }^{111}$.

A la inversa, como hallazgos hispánicos en el entorno de Hallstatt cabe citar los siguientes: un gancho de cinturón del tipo de El Acebuchal, hallado en la necrópolis de la cultura de Hallstatt tardía de Magdalenenberg, junto a VillingenSchwenningen (Selva Negra), que data de mediados del siglo VI a. C. ${ }^{112}$ Los colgantes en forma de aro y los torques de Heuneburg y de Heidenheim-Mergelstetten tienen su equivalente en tipos ibéricos, extendidos a lo largo de la costa hispánica del Mediterráneo, lo que ha llevado a Joachim Neumaier a hablar de un grupo tipológico de procedencia ibérica en Europa Central ${ }^{113}$. A ese contexto pertenecen también los colgantes con forma de animal, una modalidad del norte de Grecia que, sin embargo, está extendida tanto en la costa mediterránea de Hispania como en la Europa Central y la Italia del siglo VI a. C. ${ }^{114}$ Con todo, en esta relación predominan, en general, los hallazgos y las formas del sur y del este hispanos, pero no del oeste.

Lo expuesto hasta ahora pone de manifiesto el carácter modesto de los hallazgos de las culturas de los Campos de Urnas y Hallstatt en el oeste hispánico, que hasta la fecha se limitaban a fíbulas y, quizá, a espadas de lengua de carpa, pero que ahora pueden extenderse también a los carros con copa. Aunque, por sus características, los carros con copa puedan equipararse a objetos fácilmente transportables, tienen una trascendencia mayor que la de los otros hallazgos mencionados en lo que atañe a su significado.

\footnotetext{
105 Vilaça 2008, 82.

106 Neumaier 1995a.

107 Mansel 1998, 37-48; v. Jiménez Ávila 2003, que considera griegas las placas del cinturón y remite a estatuas griegas, en las que las hebillas se utilizan en correas de sandalias, Jiménez Ávila 2003, 39 fig. 5.

${ }^{108}$ Europa: Coffyn 1985, 135 mapa 24; Hispania: Meijide Cameselle 1988, 42 fig. 9; Stary 1994, 45-47.
}

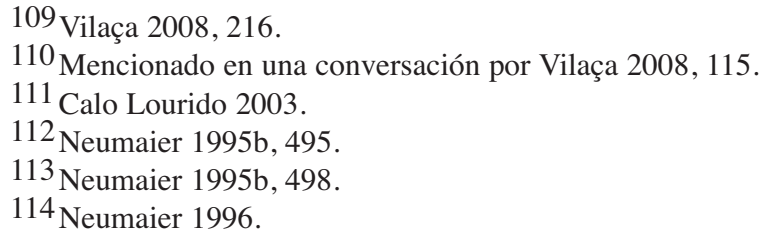

${ }^{109}$ Vilaça 2008, 216.

110 Mencionado en una conversación por Vilaça 2008, 115.

111 Calo Lourido 2003.

112 Neumaier 1995b, 495.

113 Neumaier 1995b, 498.

${ }^{114}$ Neumaier 1996. 


\section{SignificAdo}

La investigación valora este significado de forma diferente, en función, principalmente, de la interpretación del yacimiento o depósito descrito. Cuando el yacimiento y, con él, los carros con copa se interpreta como depósito de chatarra o, simplemente, como chatarra, el material hallado se define, como hemos visto ${ }^{115}$, desde un punto de vista puramente material y económico con vistas a su empleo futuro, en concreto, la refundición. La pregunta acerca de la procedencia de los carros con copa, suponiendo que no se obvie por completo $^{116}$, se responde precisamente en este mismo sentido, es decir, se consideran parte de un comercio mediterráneo de chatarra. En el caso imaginable, puramente teórico, de que los carros hubieran llegado de alguna forma al centro de Lusitania por pura casualidad, se trataría de un acontecimiento excepcional, tan espontáneo como exótico, y quedaría fuera de toda norma, por lo que no podría estudiarse desde un punto de vista científico. En este contexto y por las razones expuestas, no merece la pena seguir debatiendo acerca de la problemática denominación de «depósito», que, como se ha indicado al comienzo ${ }^{117}$, es errónea sensu stricto.

Sin embargo, junto al punto de vista descrito, cabe también otro posible. Este segundo enfoque toma en consideración la circunstancia de que, a pesar de la problemática señalada, la denominación de «depósito» es válida hasta cierto punto, puesto que los hallazgos son, en su mayoría, componentes de un complejo cerrado, es decir, un depósito. En la publicación se han incluido solo algunas piezas aisladas como hallazgos dispersos ${ }^{118}$.

En la creación de un depósito entran en juego criterios de elección. Aunque los criterios puedan omitirse aquí porque únicamente los carros con copa -y no el hallazgo completo- constituyen el tema de este artículo, los carros aportan datos sobre cuestiones secundarias relacionadas con el lugar de fabricación, sobre su integración cultural -dado que tipológicamente son únicos

115 V. el apartado El tesoro de Baiões.

116 Silva - Silva - Lopes 1984, 73-75 (depósito de un fundidor de bronce); Ruiz-Gálvez 1998, 286. 300; Senna-Martínez 2000a, 134 .

117 V. el apartado El tesoro de Baiões.

118 V. el apartado El tesoro de Baiões.

119 V. Vilaça 2008, 110. en el contexto hispánico tuvo que haber un vínculo con una región determinada, de la que procedieran los modelos originales-, así como sobre su uso y significado. A continuación examinaremos estos problemas en el orden citado.

En lo que atañe al lugar de fabricación, solo existen dos posibilidades: en primer lugar, los carros pueden haber sido importados. En este caso, cabe suponer que la población de Baiões o de una parte de Lusitania conociera la finalidad y el significado de los carros y que los utilizara en la debida forma como objetos rituales -este uso resulta, sin embargo, impensable sin el conocimiento de la utilización original y la consiguiente costumbre de uso- o que, por el contrario, los carros se utilizaran en Lusitania con un fin distinto. Se desconoce por qué vía -por mar o por tierra firme- pudo haber llegado ese conocimiento a Occidente. El debate incluye la vía por el Atlántico -en la Antigüedad, Baiões se encontraba a tan solo unos $40 \mathrm{~km}$ de la costa atlántica- ${ }^{119}$, el Mediterráneo o también por tie$\mathrm{rra}^{120}$. La segunda posibilidad contempla que los carros pudieran haber sido fabricados en Baiões o en la región circundante, hipótesis que no resulta improbable ${ }^{121}$. El aire familiar como rasgo característico de su exclusividad respalda esta teoría y los análisis del metal no la contradicen. De un lado, el molde de fundición y, de otro lado, las marcas de fundición reciente del bronce que se observan en las piezas parecen confirmar la existencia de un taller en la zona ${ }^{122}$. El oeste hispánico disponía de los necesarios conocimientos de metalurgia ${ }^{123}$. De lo anterior se extrae un argumento importante que presupone un conocimiento artesanal que solamente se pudo haber transmitido mediante el aprendizaje práctico, es decir, a través del intercambio personal entre artesanos. Es posible que ese intercambio se produjera a través de un número reducido de estaciones desde el sur de los Alpes hasta Lusitania, ya que debe suponerse un vínculo con el entorno de los Alpes, puesto que solamente allí se disponía de los conocimientos necesarios para la fabricación de los distintos tipos. Ese

${ }^{120}$ Resumen con bibliografía más antigua y la atribución a distintos grupos de población v. Mederos 2008, 446.

${ }^{121}$ Recientemente, Vilaça 2008, 130 sugiere la fabricación local con utilización de modelos orientales.

122 Senna-Martínez 1994, 219.

123 Armbruster 2000, 182; Armbruster 2003, 148. 
conocimiento artesanal tuvo que haber sido comprendido e interiorizado desde un principio, como se puede ver en la construcción del cubo de la rueda de Baiões 3. Se trata de tres partes encajadas entre sí, que, en este sentido, reflejan construcciones de cubos auténticos, como se observan en otros carros con copa, por ejemplo, en el carro de Strettweg ${ }^{124}$. Con todo, el hallazgo arqueológico de Beira Alta o del oeste de Lusitania no es suficiente para respaldar la teoría de una fabricación masiva in situ. Atendiendo a los arreos de caballos o de carros de la región, solo es posible remitirse a un punzón del depósito de Baiões que quizá represente una espuela y, en este sentido, se trate de otro indicio más del empleo de caballos en Occidente ${ }^{125}$.

Al igual que en la citada hipótesis de la importación, también en este caso la decisión de fabricar carros con copa debieron tomarla personas que los conocían y, en consecuencia, estaban familiarizados también con su uso y significado.

\section{UBICACIÓN}

Ante el trasfondo del hallazgo en el entorno de la cultura de Hallstatt mencionado al principio, en primer lugar cabe suponer un contexto funerario como destino de los carros con copa para su uso como objetos rituales en Lusitania.

Tanto en Lusitania como en otros lugares, la evolución de la Edad del Bronce a la Edad del Hierro se hace visible también, entre otras cosas, en el cambio de las costumbres funerarias y de las formas de enterramiento. En concreto, se trata de la transición de la sepultura megalítica como lugar de enterramiento colectivo a lo largo de generaciones, a la tumba individual ${ }^{126}$, cuya forma presenta distintas modalidades en la región de la Beira Alta portuguesa que aquí nos ocupa. En la mayoría de los casos se trata de tumbas de cista.

${ }^{124}$ Egg 1996, 16 fig. 7. En Hispania, la rueda de La Joya presenta una construcción similar, v. Fernández-Miranda Olmos 1986, 63 fig. 18; 70 fig. 19. - Schauer 1987, 19 destaca la construcción de la llanta y del cubo como una característica común de la construcción de carros en la Edad del Hierro tanto en Oriente como en Europa Central.

125 Silva - Silva - Lopes 1984 Est. IX Nr. 5; recientemente, Vilaça 2008, 131 y Mederos 2008, 460 fig. 38. Sobre espuelas en contextos hispánicos v. Stary 1994, 159.

${ }^{126}$ Los hallazgos que se describen a continuación son asimismo interesantes porque demuestran la existencia de
Algunas se hallan debajo de un túmulo (tumulus), que, sin embargo, puede faltar en alguna ocasión. Asimismo, existen enterramientos en fosas (fossae), cuevas y abrigos rocosos. La inhumación propiamente dicha consiste en la mayoría de los casos en la deposición del cuerpo (tumba de inhumación) y con menor frecuencia, en la incineración (tumba de incineración). La costumbre de la incineración no es en absoluto un fenómeno tardío y, por lo tanto, no debería relacionarse necesariamente con la penetración de la cultura de los Campos de Urnas en la Península Ibérica, como sucede a menudo ${ }^{127}$. En las tumbas de inhumación está documentado asimismo el traslado del cadáver de una tumba a otra y en las de incineración, tanto la incineración de todo el cuerpo como la de solo partes del mismo. Además de las modalidades citadas, hay también tumbas vacías, es decir, cenotafios, y, en otras, se ha llevado a cabo la separación de los huesos y la carne del cadáver (descarnadura) ${ }^{128}$. No es habitual que haya ajuar funerario; cuando existe, suele ser de metal y no aparecen armas en absoluto ${ }^{129}$.

Sin embargo, la interpretación de todas estas formas de enterramiento tan distintas entre sí origina abundantes problemas. Aunque existe un número elevado de tumbas conocidas (fig. 10), hasta ahora solo se han excavado unas pocas. Tanto su forma como sus contextos son muy diferentes ${ }^{130}$. Así, encontramos necrópolis sin el asentamiento humano correspondiente, como la de Paranho, necrópolis sin deposiciones funerarias, como la de Senhora da Ouvida, y tumbas sin asentamiento, como las de São Julião o Santinha ${ }^{131}$. Estos hallazgos se explicarán brevemente a continuación, pues quizá puedan contribuir a aclarar las razones de esa diversidad tipológica y, con ello, ayudar a esbozar un panorama general. El mapa (fig. 10) se centra, a su vez, en la difusión de las tumbas y necrópo-

tumbas y necrópolis en la Edad del Hierro que algunos investigadores habían negado recientemente; v. resumen en Vilaça - Cruz 1999, 75

${ }^{127}$ Vilaça - Cruz 1999, 80

128 Resumen en Vilaça - Cruz 1999, 76-85.

${ }^{129}$ Vilaça - Cruz 1999, 87

130 Vilaça 2008, 111.

${ }^{131}$ Paranho: Cruz 1997, 103; Senhora da Ouvida: Cruz Vilaça 1999; São Julião: Martins 1988, 135; Santinha: Bettencourt 1995, 113. 
lis en la zona de Baiões, así como en el centro de la Lusitania occidental, entre los ríos Duero y Tajo. Los hallazgos de tumbas situados fuera de dicho territorio no figuran en el mapa. La tumba n. ${ }^{\circ} 18$ se ha incluido únicamente para localizar el punto del hallazgo mencionado en el texto $^{132}$.

En la necrópolis de Senhora da Ouvida (fig. 10, n. ${ }^{\circ}$ 4) se han encontrado 25 tumbas de túmulo: la mayoría mide entre 5 y $10 \mathrm{~m}$ de diámetro, y la mayor, $16 \mathrm{~m}$ de diámetro. En general, están construidas a modo de cairns, es decir, montículos formados con piedras (granito y cuarzo). Los bordes del túmulo están delimitados con piedras colocadas

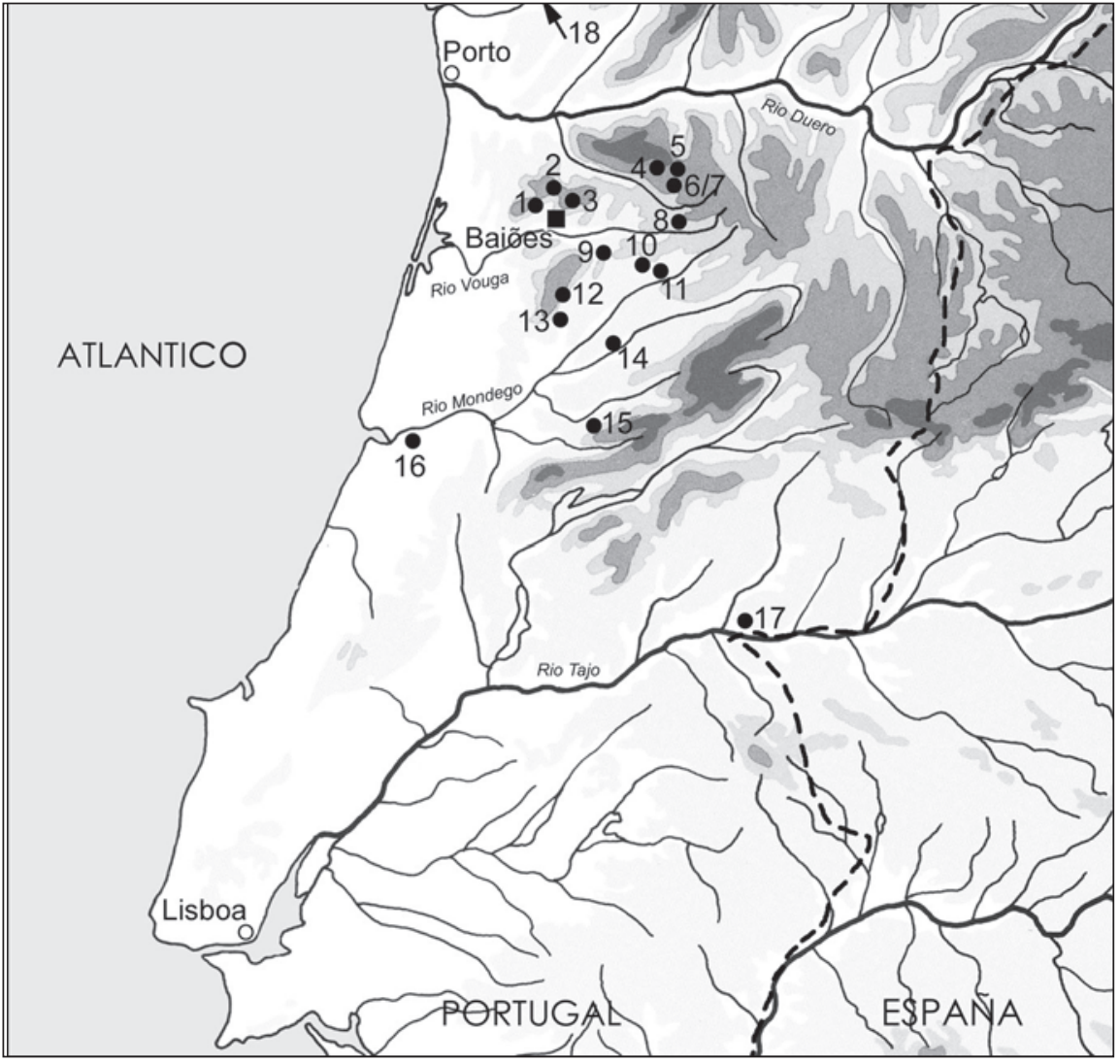

Figura 10 en posición horizontal. Unas pocas tumbas (núms. 10 y 12) poseen una estructura interna en forma de piedras dispuestas en el centro de un círculo. En este lugar, la excavación sacó también a la luz tierra de relleno, por lo que cabe suponer que se trata de una cámara mortuoria, tal como se conoce de otras tumbas de túmulo de la región ${ }^{133}$.

Curiosamente, los túmulos se hallaron completamente vacíos, a excepción de una hoja de sílex, que lo más probable es que llegara allí por casualidad. No obstante, en el horizonte de ocupación se observan regularmente restos de carbón vegetal anteriores a la época en la que se construyó la tumba. Por ello, los arqueólogos Cruz y Vilaça suponen que las cenizas o, en su caso, los restos de los difuntos fueron depositados en las tumbas. La incineración del cadáver debió de efectuarse en otro lugar ${ }^{134}$. Los escasos restos de ceniza no permiten pensar que esta se depositara en su totalidad, sino solo una parte. En este sentido, podría tratarse de un depósito simbólico. Otra explicación posible es suponer la existencia de pequeños hogares que se encontraban allí ya antes de la construcción de las tumbas o que se dispusieron específicamente para ello. Se datan entre los siglos XV y VIII a. C.

El mejor paralelo con las costumbres funerarias centroeuropeas (Campos de Urnas) lo ofrecen probablemente las necrópolis de Paranho y São Julião, pues en los túmulos se utilizaron urnas para recoger las cenizas de los muertos. En Paranho (fig. 10, n. ${ }^{\circ}$ 13) se trata de seis enterramientos por incineración, del siglo XII/XI a. C., en cistas muy parecidas, casi cuadradas, de unos $30 \times 40 \mathrm{~cm}$, pero de $75 \mathrm{~cm}$ de fondo, que están dispuestas dentro de un semicírculo de losas colocadas de canto, de manera que el punto central del círculo queda libre. En el círculo de piedra se hallaron seis tumbas, cada una de las cuales contenía un único individuo. En dos casos, las cenizas del difunto se habían recogido en sendas vasijas, que, a pesar de su estado fragmentario, per-

\footnotetext{
${ }^{132}$ Sobre otras necrópolis y tumbas de la Lusitania central, v. $\quad{ }^{133}$ Enumeración y descripción en Cruz - Vilaça $1999,132$. Cruz - Vilaça 1999, 79-85. 
miten identificar que una de ellas carecía de asas y la otra disponía de carena, en parte ausente, y tenía el fondo perforado. Asimismo aparecen con regularidad objetos de bronce, tales como brazaletes, cazoletas o fíbulas (?). Las cajas estaban cerradas con losas colocadas en horizontal. En lo que atañe a la costumbre funeraria, el arqueólogo Domingos Cruz remite al paralelismo con la cultura de los Campos de Urnas, a la vez que resalta el carácter singular de los enterramientos mencionados, puesto que en la región de Beira Alta no hay ningún ejemplar comparable ${ }^{135}$. Un hallazgo muy parecido en cuanto al uso de urnas, aunque con solo dos túmulos apenas excavados, lo constituye claramente São Julião (fig. 10, n. ${ }^{\circ} 18$ ), que, por cierto, se encuentra fuera de la región ${ }^{136}$. El hallazgo de Santinha consiste en una cista $(50 \times 40 \times 28 \mathrm{~cm} \mathrm{de}$ fondo), cubierta con piedras, es decir, sin túmulo. En el interior se encontraba una pequeña vasija fragmentada y cerrada, así como restos aislados de carbón vegetal. La vasija muestra huellas de ahumado en el exterior ${ }^{137}$.

En resumen, se puede afirmar que el inventario funerario parece, en general, antiguo y autóctono; no existen objetos que den la impresión de ser foráneos o importados ${ }^{138}$. Aparentemente, los contextos funerarios no reflejan influencias del exterior. En tumbas de este tipo resultan inimaginables los carros con copa como ajuar funerario: parecerían fuera de lugar $\mathrm{y}$, por lo tanto, elementos extraños.
Como ubicación y lugares de uso más allá de las tumbas quedan los lugares de culto y los santuarios, respectivamente. Esta posibilidad merece ser tomada en consideración, entre otras razones, porque ya Antígono de Caristo informa acerca de la existencia de un carro sagrado de metal, que en la ciudad tesalia de Cranón se movía enérgicamente de un lado a otro en épocas de sequía mientras se imploraba a la divinidad para que enviara la lluvia' ${ }^{139}$.

En la época que aquí interesa, en Lusitania se conocen pocos santuarios de los que se sepa con seguridad que fueron utilizados para fines religiosos ${ }^{140}$; quizá tan solo Cachouça y Fráguas (fig. 11). Cachouça se encuentra en el extremo meridional del espacio en cuestión, no lejos del valle del Tajo ${ }^{141}$. Entre los hallazgos destacan,

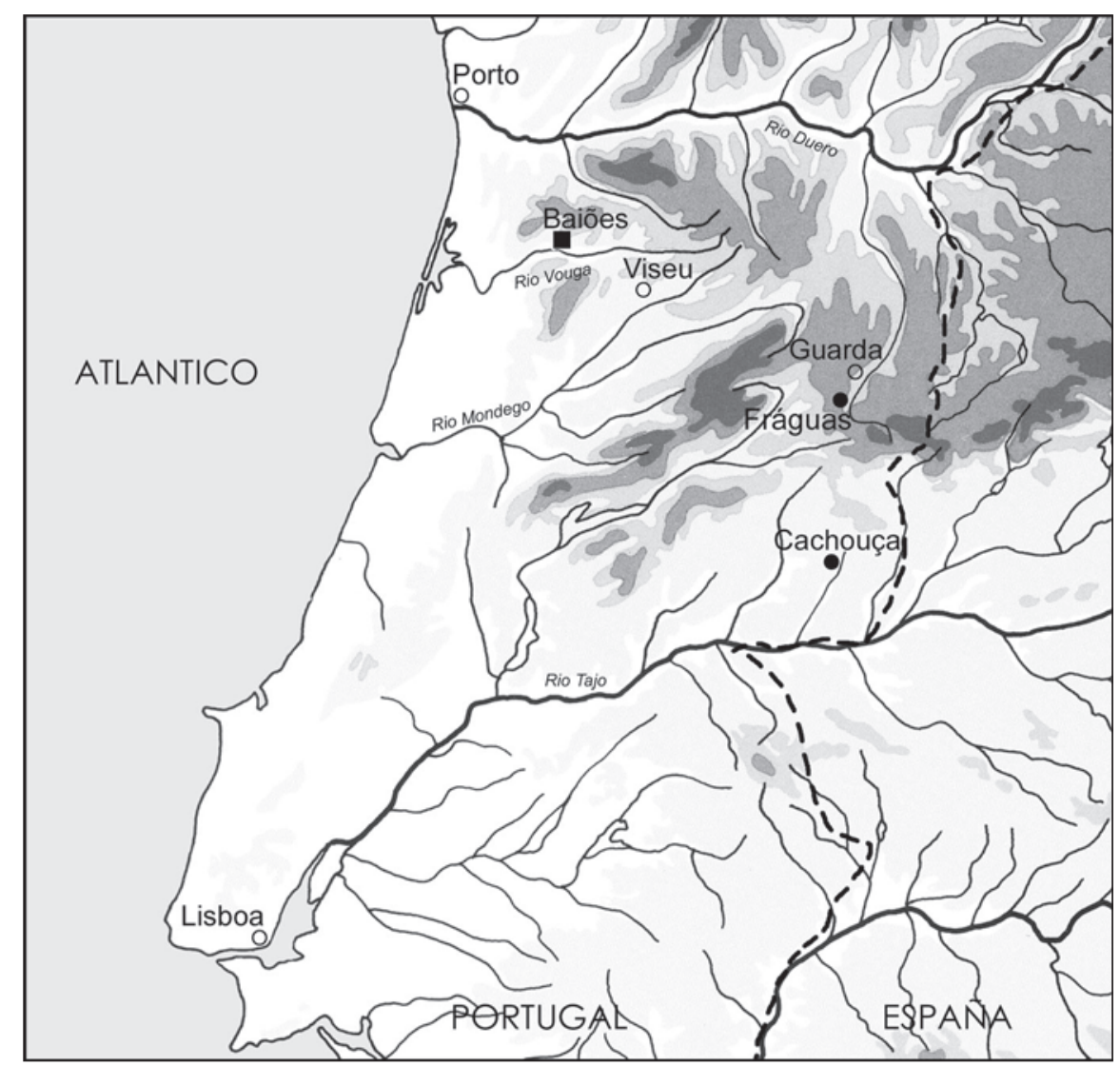

Figura 11
${ }^{135}$ Cruz 1997, bev. 100. 103; Vilaça - Cruz 1999, 86.

${ }_{136}$ Martins 1988, 135 y s.

137 Bettencourt 2001, 32.

138 Vilaça 2008, 111. 156.

${ }^{139}$ Furtwängler 1893, 259. Asímismo, Teresa Chapa las relaciona con un supuesto santuario en el Castro, V. Chapa 2003.201.
140 Aquí no se han tenido en cuenta >lugares sagrados<, que destacan por sus pinturas rupestres o por otras características (v. p. ej. Vilaça - Cruz 1999, 87), o santurios en rocas como el célebre de Panóias.

${ }^{141} \mathrm{La}$ arqueóloga $\mathrm{R}$. Vilaça ha informado en diferentes ocasiones sobre la excavación; recientemente, Vilaça 2008, 70-74. 
precisamente por no ser comunes en la Lusitania central, cuentas de cristal, figuras de animales de terracota, utensilios de hierro y cerámica gris torneada. Mientras que estas piezas se pueden atribuir claramente al ámbito fenicio-mediterráneo, otras, como la cerámica con decoración de marcas de peine, muestran, por el contrario, un vínculo con la meseta septentrional de la Hispania central que limita directamente con el noreste. La diversidad de las relaciones exteriores resulta llamativa, pero tampoco es atípica de un santuario. No obstante, la interpretación del lugar como santuario se basa también en otro hallazgo. En concreto, se trata de una superficie ahondada más o menos circular (39 x 26 m), delimitada en todos sus lados por una tapia de cascajo y tierra ${ }^{142}$. La cara exterior está ataludada y se supone que la entrada se encontraba en el lado suroriental. A lo largo de la tapia hay cinco piedras sin labrar clavadas en el suelo a intervalos, y todas presentan la particularidad de acabar en punta. En cortes practicados en la tapia se descubrieron dos vasijas. Una es una olla que se había conservado casi completa y que se interpreta como depósito primitivo debido a que se encontró en la base de la tapia $^{143}$. La otra, en cambio, se descubrió en un nivel más alto, cerca del borde superior de la misma. Se trata de un cuenco con decoración de marcas de peine que fue destruido intencionadamente in $s i t u^{144}$. Mientras que la primera vasija se halló en la parte occidental de la tapia, la segunda se encontró en la oriental. A las vasijas se añaden piedras con cazoletas, de las que se pueden observar no menos de ocho en el entorno inmediato de la tapia. Todas las características juntas constituyen una explicación convincente para interpretar el lugar como un santuario de fina- les de la Edad del Bronce o principios de la Edad del Hierro.

La interpretación de Cabeço das Fráguas (Guarda) como santuario es asimismo evidente gracias a una inscripción que, en alfabeto latino, aunque en lengua lusitana, informa de un caso clasificable como suovetaurilia (sacrificio de un cerdo, una oveja y un toro) (fig. 12) ${ }^{145}$. La inscripción data del siglo I d. C. , pero es muy probable que el santuario existiera ya con anterioridad, en época prerromana, tal como sugieren algunas particularidades, entre ellas, los dos habitáculos circulares excavados, que poseen un diámetro llamativamente grande, de bastante más de $7 \mathrm{~m}$ (fig. 13). Otro indicio es asimismo la ausencia de hogares en el interior, así como el repertorio de cerámica, que destaca por consistir en pequeñas vasijas abiertas, mientras que los recipientes para guardar provisiones y para cocinar, habituales en los asentamientos humanos y de los que se han encontrado grandes cantidades, son muy escasos o faltan por completo. Un parecido arquitectónico con Cachouça podría consistir en que la superficie considerada area sacra se encuentra delimitada igualmente por un muro de

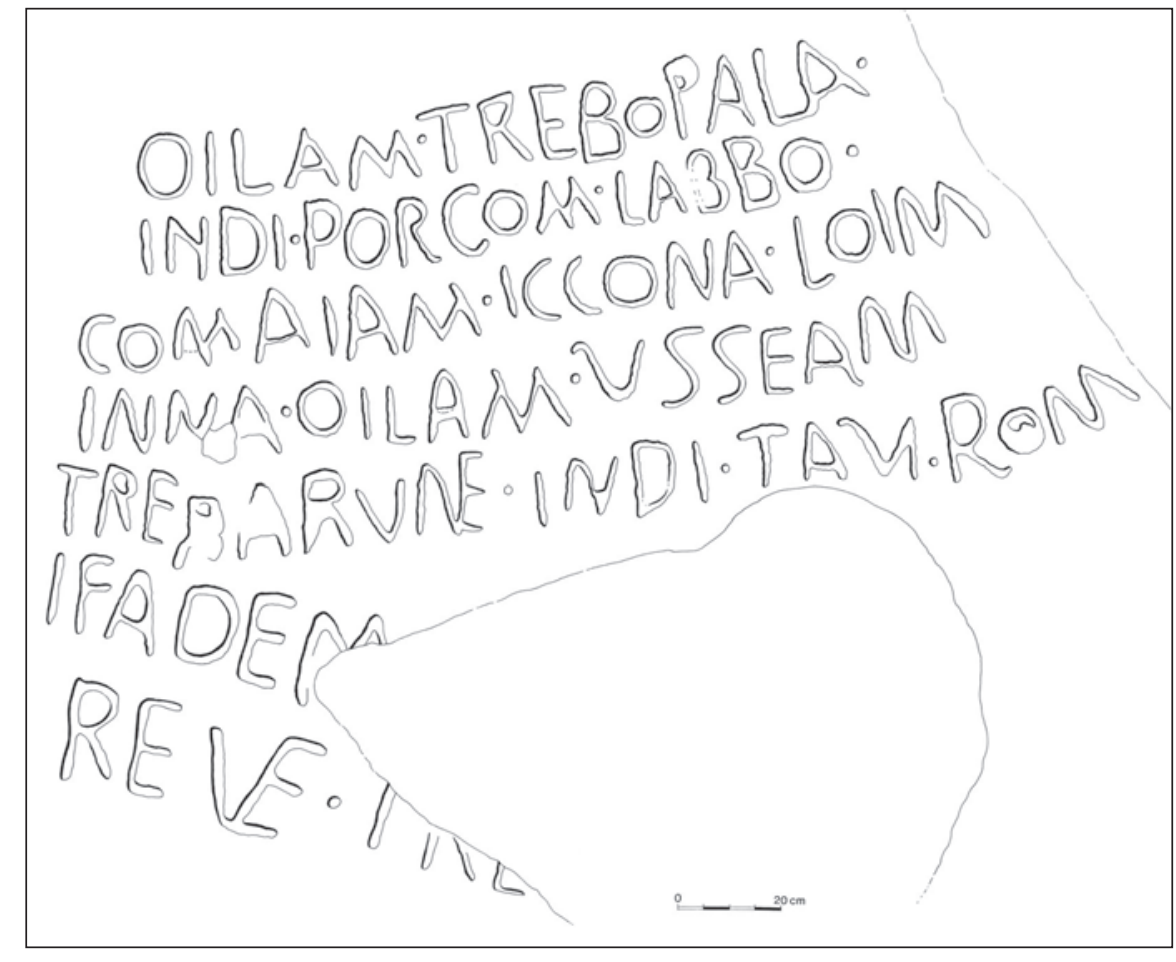

Figura 12: J. Fernández, DAI Madrid

142 Vilaça 2008, 48 fig. 14; 72 fig. 28.

143 Vilaça 2008, 73 fig. 29.

${ }^{144}$ Vilaça 2008, 73 fig. 30.

${ }^{145}$ Schattner - Santos - Pereira 2008. 


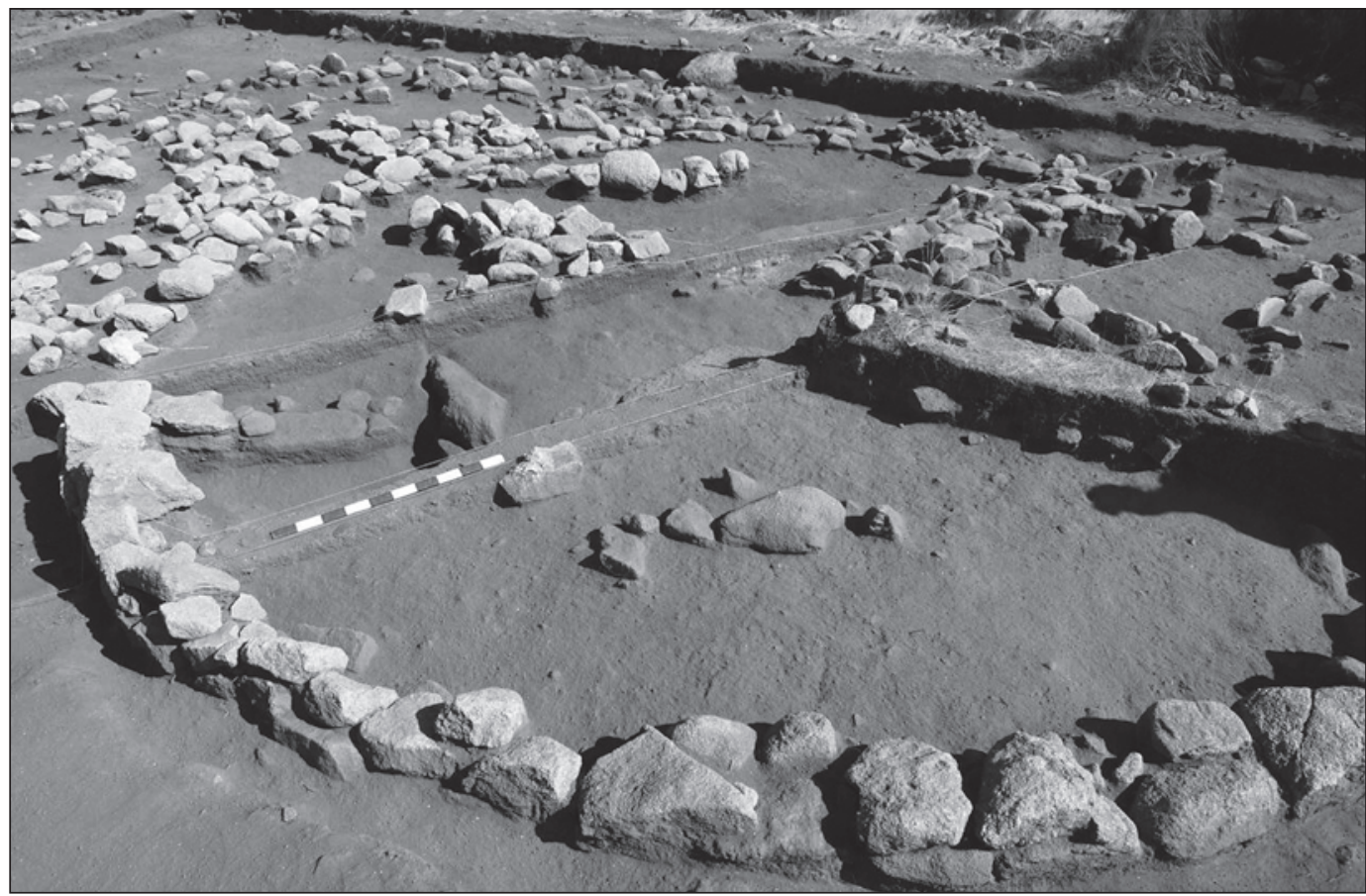

Figura 13: NegNr. D-DAI-MAD-PAT-06-025-09-022

piedra (fig. 14). Entre los hallazgos alógenos cabe destacar también la presencia de cuentas de cristal $^{146}$. Los dos santuarios muestran de forma palmaria rasgos totalmente autóctonos en su estructura.

En resumen, se puede afirmar que los carros con copa resultan sumamente imaginables en un entorno como el de los santuarios descritos. En el marco del conjunto de piezas foráneas asimismo habituales -fíbulas, pinzas, la banda trenzada como motivo decorativo en objetos de bronce, pasta de vidrio o cuentas de cristal y utensilios de hierro $-{ }^{147}$, no llamarían tanto la atención como elementos extraños. Del hecho de que no se trata de un solo ejemplar, sino de tres como mínimo, se debe deducir necesariamente una cierta difusión y un uso similar en Lusitania.

En cuanto al uso, los carros con copa apenas sirven para otra cosa que para contener sustancias

${ }^{146}$ En el Occidente hispánico, las cuentas de cristal ya eran conocidas, al parecer, en época precolonial; v. en general Vilaça 2008, 149 y s. En este contexto quizá convendría remitir también a los artefactos de ámbar presentes en la región y que, evidentemente, proceden del Báltico: Vilaça - Beck - Stout 2002.

147 Vilaça 2008, 145-152.

148 Barnett 1957, 145, nota 1; Matthäus 1985, 321; Mederos Harrison 1996, 237-254.

${ }^{149}$ En analogía con los carros con copa del Antiguo Testamento, v. Weippert 2006, 112 y s., cuyos recipientes valiosas, como incienso ${ }^{148}$, o algún líquido ${ }^{149}$. Es posible que en ellos se quemara incienso o que se bebiera o libara algún líquido, operación que se realizaría en movimiento sobre un soporte con ruedas, apenas más alto de $10 \mathrm{o} 15 \mathrm{~cm}$. Diferentes voces han señalado que en el Bronce Final se comerciaba abundantemente con este tipo de soportes para vasijas, tal como atestiguan los hallazgos correspondientes del pecio del cabo Gelidonia ${ }^{150}$. De ello puede deducirse el consiguiente conocimiento de su uso. Por tanto, si los carros con copa se empleaban en el culto fúnebre en Europa Central y se movían en las ceremonias funerarias, no hay que descartar que cumplieran esa misma función en los santuarios de Lusitania durante las ceremonias religiosas ${ }^{151}$. Los ritos funerarios y los que se practicaban en los santuarios no tienen por qué ser fenómenos opuestos y excluyentes. El hecho de que la situación de la cerámica de figuras rojas, muy difundida tanto en el lejano Este como en el Oeste, se plantee de forma podían contener, comparativamente, enormes cantidades de líquido.

${ }^{150}$ Mederos -Harrison 1996, 242; Weippert 2006, 99 con nota 108.

${ }^{151}$ Los investigadores se muestran a menudo escépticos, v. Vilaça 2008, 157; p. ej., Senna-Martínez 2000a, 129 considera la circulación de mercancías como mercaderías basándose únicamente en su valor material o económico. Tan solo se habría adoptado la forma, pero no el significado de las piezas. 


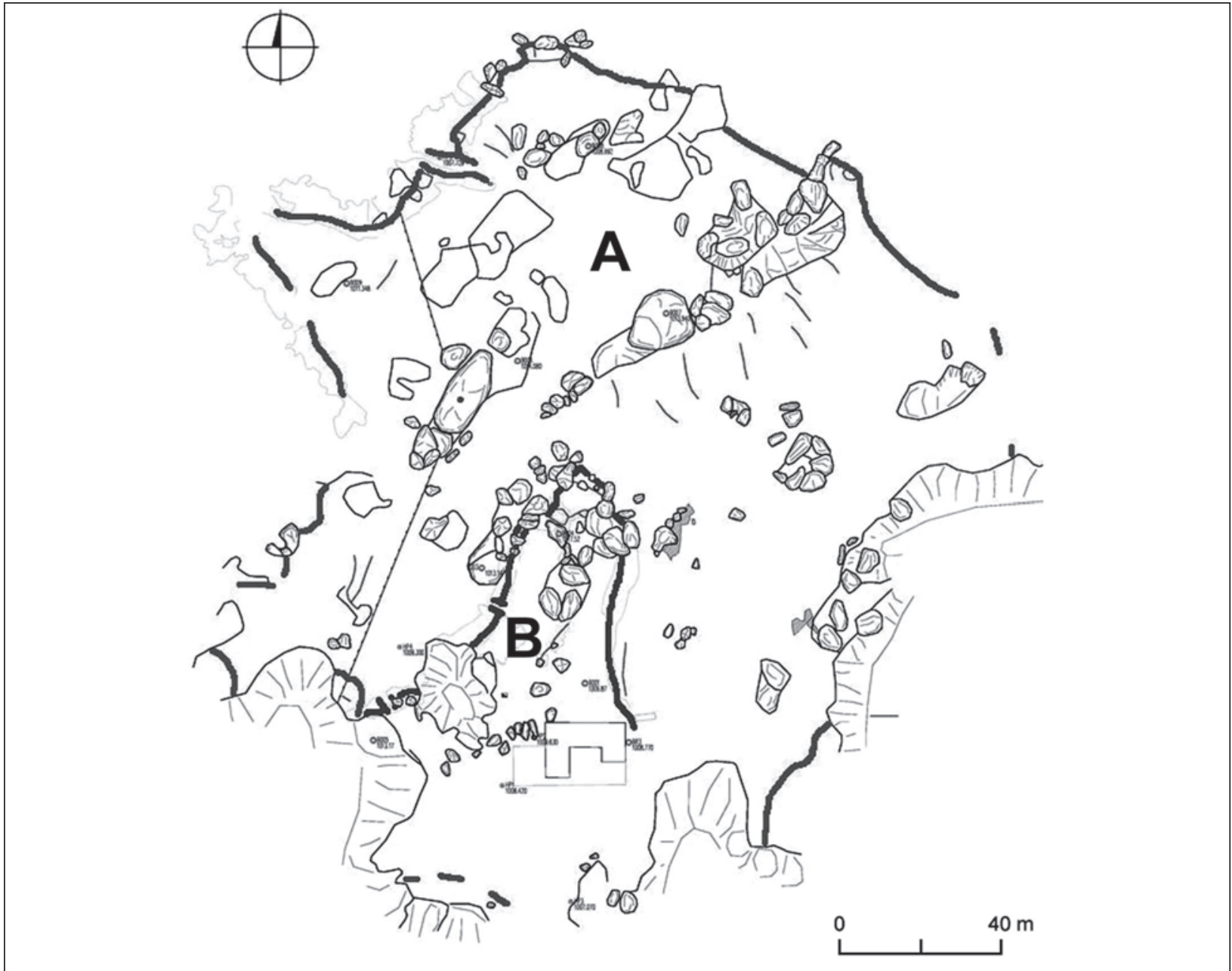

Figura 14: Planaufnahme Chr. Hartl-Reiter, DAI Madrid.

distinta o, dicho de otro modo, que en el caso de las vasijas no se adoptara su uso original, como ha demostrado recientemente Friederike Fless ${ }^{152}$, está relacionado con toda una serie de imponderables: las vasijas son un producto masivo, mientras que los carros con copa son obras fabricadas individualmente; se comerciaba con ungüentarios debido a su contenido, mientras que las cráteras de campana se consideraban artículos de gran consumo sin un uso especial, etc.

\section{Los Carros en la Hispania occidental}

El hecho de que en la Lusitania central se emplearan de repente los carros con copa para

${ }_{152}^{152}$ Fless 2002, 97.

${ }^{153}$ El fenómeno no es exclusivo de Hispania (Stary 1994, 164 175). Tal como señala Höckmann 1982, 151, los hallazgos del siglo VII a. C. indican que los carros constituían los componentes más numerosos de los ajuares funerarios también en el ámbito etrusco. Resumen en Quesada - Blázquez 2005.

${ }^{154}$ Información recopilada y elaborada recientemente por realizar determinados actos, relacionados muy probablemente con el culto, debe verse también en el contexto de los carros propiamente dichos, representados en abundancia en Hispania, y, en particular, en el oeste y el sudoeste, a partir del siglo VII a. C. ${ }^{153}$ La mayoría aparece en las «estelas extremeñas», interpretadas en parte como estelas funerarias ${ }^{154}$. Las estelas son monumentos extraordinarios que encarnan el comienzo del arte narrativo en la Hispania de la Edad del Hierro y, como tales, un importantísimo indicador de la disposición de los pueblos limítrofes del Mediterráneo a aceptar impulsos foráneos ${ }^{155}$. De un total de 93 estelas, 21 contienen representaciones de $\operatorname{carros}^{156}$. Además de con carros, las

Celestino Pérez 2001 211-232 con especial incidencia sobre las representaciones de carros. Atractivo mapa de difusión de las estelas con reproducciones de carros en Quesada Blázquez 2005, 47.

155 Parzinger 1991,31 y s. 36.

156 Celestino Pérez 2001, 213-215 fig. 54; Harrison 2004, 147 fig. 7,16; Mederos 2008, 442 fig. 2. 
estelas están decoradas con dibujos de guerreros armados, espejos, peines, instrumentos musicales y otros objetos. Dado que la iconografía y la composición de las estelas están establecidas canónicamente, es obvio que los carros -casi siempre de dos ruedas- se incorporaron en fecha posterior ${ }^{157}$. Las imágenes destacan por la alternancia de la perspectiva: el carro se representa siempre visto desde arriba, mientras que las ruedas aparecen junto a él como desplegadas. Como es sabido, esta forma de representar un carro es característica del ámbito indoeuropeo, o mejor dicho no-mediterráneo y se encuentra en todo el espacio que se extiende desde la Europa septentrional hasta la meridional, pasando por la central ${ }^{158}$. Además de en las estelas, esa forma de representación aparece también en otros soportes, tanto en el arte rupestre como en «vasijas mailhacienses», pero siempre en un número comparativamente menor ${ }^{159}$. La observación de que el lugar del hallazgo de este arte rupestre se encuentra en la Península Ibérica, en el abrigo rocoso de Los Buitres de Peñalsordo (provincia de Badajoz), es decir, en la zona de difusión de las estelas, resulta particularmente interesante ${ }^{160} . \mathrm{La}$ relación resulta obvia: tanto en las rocas como en las vasijas y en las estelas, el carro aparece representado según la tradición no-mediterránea, es decir indoeuropea. El hecho de que los carros de las estelas tengan dos ruedas y en planta posean la forma de una lira está documentado suficientemente en las citadas pinturas rupestres indoeuropeas ${ }^{161}$.

Esta técnica de representación indoeuropea se distingue en gran medida de la greco-feniciomediterránea, que, aunque alterna la perspectiva, reproduce siempre el carro de perfil ${ }^{162}$. La

157 Celestino Pérez 1985, 47; Fernández Miranda - Olmos 1986, 97; Celestino Pérez 2001, 217. 221; Mederos 2008, 445. Las remisiones a vehículos de cuatro ruedas o a carros son muy escasas tanto en las estelas como en la Península Ibérica en general; v. Fernández Miranda - Olmos 1986, 97. 110; Joya Guerrero 1998, 84.

${ }^{158}$ En el contexto hispánico citado recientemente por Celestino Pérez 2001, 225 con fig. 58. 159 Vasijas y arte rupestre: Arnal - Prades 1976, 41 con fig. 1. 2; en el contexto hispánico citado por Fernández Castro 1988, 520-522 con. 620 Arte rupestre: Berg-Osterrieth 1972, 120; Sevillano 1976, 258-262; Celestino Pérez 2001, 225 con fig. 58.

${ }^{160}$ Breuil 1933, 63 fig. 20 Tav. s. 28. 29; Almagro 1966, 193; Acosta 1968, 102-104 mit fig. 28; Celestino Pérez 2001, 226 fig. 59. Mapas de difusión de las estelas en Celestino Pérez 2001, 95 fig. 15; Harrison 2004, 39 fig. 4, 2; Mederos 2008, 444 fig. 5. - Joya Guerrero 1998, 86 y s. se muestra escéptico en lo que atañe a interpretar los dibujos rupestres como imágenes de carros utilizando como argumento un técnica era conocida también en la Península Ibérica y aparece, por ejemplo, en algunos monumentos coetáneos, tales como un relieve de marfil de Alcantarilla (Sevilla) ${ }^{163}$, un dado de Cancho Ruano ${ }^{164} \mathrm{y}$, de época posterior, un friso de Almodóvar del Río y otro de Illescas ${ }^{165}$. Sin embargo, dicha técnica no se utilizó en las pinturas rupestres y estelas en cuestión. Por ello resulta incomprensible que en la bibliografía más reciente se defienda al unísono la relación de los carros representados en las estelas con el mundo mediterráneo, en concreto, con carros micénicos ${ }^{166}$. La razón parece ser que la vista se dirige en primer lugar a los detalles más remotos, tales como las ruedas, su número y el número de radios, para desplazarse a continuación a la interpretación funcional y a la trasposición conceptual, pasando por alto el rasgo esencial, a saber, el carácter de la forma de representación, así como el hecho de que se trata precisamente de reproducciones que deben incluirse, ante todo, en el estilo de representación bidimensional, no equiparables necesariamente a los carros auténticos sin prestar antes atención a las circunstancias correspondientes. La forma de representación que aquí nos ocupa depende, en primer lugar, de la tradición estilística, y las imágenes no pretenden reproducir fotográficamente la realidad, por lo que no pueden convertirse sin más en una copia exacta de esta. Naturalmente, las imágenes poseen siempre una relación con la realidad, relación que es preciso elaborar y tener en cuenta. Ante ese trasfondo y atendiendo a la calidad de las representaciones, el intento de definir los carros funcionalmente

círculo vicioso: si las representaciones de carros se localizan en un ambiente aristocrático, que, al parecer, no se daba en cuevas y abrigos rocosos, no puede tratarse de representaciones de carros.

${ }^{161}$ Dos ruedas: Berg-Osterrieth 1972, 120; forma de lira: Celestino Pérez 2001, 225 fig. 58 (según M. P. Malmer, non vidi).

162 Celestino Pérez 2001, 214. 227 fig. 60; Mederos 2008, 445. 450 fig. $15.16 ; 451$ fig. $17.18 ; 454$ fig. $23.25 ; 455$ fig. 26-28.

163 Fernández Miranda - Olmos 1986, 116 Tav. s. 23.

164 Celestino Pérez 2001, 231 fig. 61.

165 Fernández Miranda - Olmos 1986, 109 Tav. s. 20; 111 Tav. s. 21.

166 Bendala Galán 1977, 185; Bendala Galán 1979, 33; Celestino Pérez 1985, 54; Fernández Miranda - Olmos 1986, 102; Celestino Pérez 2001, 227. 230; Harrison 2004, 183; Mederos 2008, 461. La historia de la investigación completa con pruebas en Mederos 2008, 446. 
(carros de transporte, de guerra, funerarios) ${ }^{167}$ quizá parezca superfluo, puesto que el contexto clarificador correspondiente no está representado en las estelas o, al menos, hasta ahora no nos resulta reconocible o evidente. A pesar de ello, se ha adelantado una interpretación hipotética, que exije un alto grado de presuposiciones. La argumentación es la siguiente ${ }^{168}$ : el contexto es funerario porque los carros aparecen en los contextos funerarios correspondientes tanto de Europa Central (enterramientos con carros en la cultura de Hallstatt) como del mundo greco-mediterráneo (representaciones de la ekphorá en la pintura de vasijas geométrica y presencia de carros en las tumbas de la necrópolis de La Joya). De este modo, tratándose de carros funerarios, quedarían excluidas otras atribuciones, como las de carros de transporte o de guerra. De otro lado, puesto que cabe suponer que, en la época en cuestión, en el suroeste hispánico predominaba ya el enterramiento por incineración, no se celebrarían exequias ni procesiones en las que se transportara el cadáver del difunto en un carro.

En este punto, resulta oportuno señalar que el destino de la ekphorá es, por supuesto, la pira, es decir, el ustrino o busto, por lo que es posible que se utilizara el carro con tal fin. A la vista de la datación alta de las estelas en el siglo VIII a. C., en esta argumentación no cabe la relación con los carros de las tumbas 17 y 18 de la necrópolis de La Joya, puesto que pertenecen ya al siglo VII a. C.; en todo caso, podrían relacionarse con las estelas tardías. Según esta interpretación hipotética, todas las reflexiones apuntadas solo pueden llevar a la conclusión de interpretar las escenas reproducidas en las estelas como representación del viaje que el difunto emprende al más allá a bordo de un carro, adscribirlas a un ámbito intelectual y negar toda relación con la realidad ${ }^{169}$.

167 Celestino Pérez 2001, 231.

168 Celestino Pérez 2001, 229-232.

${ }^{169}$ Resumen en Joya Guerrero 1998, 83 y Celestino Pérez 2001, 231

170 Harrison 2004, 114; Mederos 2008, 460.

171 Höckmann 1982, 150. 154. 156. 157.

${ }^{172}$ Celestino Pérez 2001, 231. Resumen sobre la investigación de la cronología en Joya Guerrero 1998, 85.

173 Fernández Miranda - Olmos 1986, 49-96. 113. 117-125.

${ }^{174}$ Celestino Pérez señala que las estelas extremeñas están diseminadas en una zona en que abundan las colinas e
Esta opinión recae en círculos viciosos y, por ello, ha suscitado controversia en repetidas ocasiones ${ }^{170}$. Harrison, por ejemplo, señala acertadamente la función del carro como indicador del estatus social. En otro contexto, Ursula Höckmann comenta que ni en los monumentos griegos ni en los etruscos se detecta la idea del viaje del difunto al más allá, sino que este recorre el camino al Hades siempre a pie ${ }^{171}$. A continuación esta autora describe en qué ámbito y en qué ocasiones se utilizaban carros en la Antigüedad, y sus explicaciones resultan muy reveladoras para la situación hispánica.

Si en el arte rupestre $-y$, por tanto, en las estelas extremeñas- las representaciones de carros muestran una estrecha relación con la tradición no-mediterránea, pero sí indoeuropea, como se ha demostrado, de ello cabe extraer otro argumento para los carros con copa de Baiões, que apoya la teoría de los vínculos del oeste central hispánico con Europa Central.

En lo que atañe a la cuestión de si existieron carros auténticos en la realidad, los relieves mencionados parecen indicar que, efectivamente, había carros de dos ruedas del tipo que aparece representado y que quizá se emplearan con cierta profusión en esa época. Lamentablemente, los hallazgos arqueológicos son escasos. Aparte de los famosos carros de dos ruedas de la necrópolis de La Joya (Huelva) ${ }^{172}$, solo se conocen ruedas aisladas y modelos de carros $^{173}$, especialmente porque faltan también las infraestructuras de calzadas y $\operatorname{caminos}^{174}$, por lo que sigue sin conocerse la participación de los carros en el volumen de tráfico de la Península Ibérica ${ }^{175}$.

El carro en sí se introduce en la Península Ibérica en el siglo XI a. C., según atestigua el vestigio más antiguo que se conoce: una mordaza de hueso procedente de la excavación de Fuente Álamo ${ }^{176}$. Desde esta época hasta la indi-

incluso las montañas, por lo que los carros no podrían circular fácilmente por ella y utiliza esta observación como argumento práctico para apoyar su opinión de que en Hispania no se utilizaron carros de verdad; v. Celestino Pérez 1985, 50-52; Celestino Pérez 2001, 230.

175 Algunos autores niegan incluso la existencia de carros antes de la época orientalizante; v. lista completa en Mederos 2008, 460.

176 Arteaga - Schubart 1980, 273 fig. 273 n. ${ }^{\circ} 12$ o; Fernández Miranda - Olmos 1986, 69; Brandherm 2009, 32.

Recopilación de dataciones más antiguas en Joya Guerrero $1998,86$. 
cada de los carros con copa, las pinturas rupestres y las estelas del Bronce Final o de la época orientalizante del siglo VII a. C. faltan los eslabones intermedios ${ }^{177}$. En ambos casos, la existencia de arreos de caballos y herrajes de carros significa el comienzo de una nueva época ${ }^{178}$.

\section{Conclusión}

A finales de la Edad del Bronce, el Occidente hispánico produce metal, en concreto, bronce, por primera vez en su historia. Todos los lugares de la región de cierta importancia aportan indicios inequívocos: escorias, cáscaras y moldes de fundición e incluso hornos, tal como revelan las excavaciones ${ }^{179}$. El estaño se obtiene de las numerosas minas que existen en la zona, donde, sin embargo, no se da el cobre -imprescindible, en cantidades mucho mayores, para la obtención de bronce-, por lo que es necesario conseguirlo en otros lugares. Este hecho origina por sí solo un movimiento natural de ida y vuelta hacia los yacimientos de cobre, entre los que destacan los existentes en el suroeste hispánico. La elección de esos yacimientos como fuente de suministro de cobre obedece a dos razones: de un lado, porque ya fueron explotados en la Edad del Cobre y, de otro, por la abundancia de metal ${ }^{180}$. Aunque las cantidades son más bien pequeñas, por lo que prácticamente no puede hablarse de comercio ${ }^{181}$, el oeste hispánico empieza a ser conocido cada vez más -también en lo que atañe a su pasado, como prueba el anillo de oro del II Milenio a. C. importado de Baiões, mencionado al principiopor sus minas de estaño y sus objetos de bronce, despertando así el interés de los navegantes fenicios. Los productos en sí responden al canon formal tanto de la Edad del Bronce atlántica como

${ }^{177}$ Los hallazgos del depósito de la Ría de Huelva, considerados en ocasiones como arreos de caballos y herrajes de carros (recientemente reproducidos y comentados en Mederos 2008, 460 con fig. 39), sin embargo no pueden atribuirse a esa función con claridad, v. Brandherm 2009.

178 Así ocurre también en otros lugares. Tal como señala Gabrovec 1980, 31. 40, la presencia de bronce en los arreos de caballos marca el comienzo de la cultura de Hallstatt; los pueblos de los Campos de Urnas no lo utilizaron para tal fin. Stary 1994, 150 y s. describe la situación hispánica.

179 Senna-Martínez 1994, 223; Senna-Martínez 2005, 905.

${ }^{180}$ Castro Nunes supuso ya en las décadas de los años cincuenta y sesenta la existencia de un corredor comercial de la época orientalizante ${ }^{182}$. Entre el área de difusión de la Edad del Bronce atlántica y el entorno del Mediterráneo había muchas conexiones ${ }^{183}$.

En las regiones limítrofes aparecen los consiguientes objetos de bronce; ambas áreas -el Atlántico y el Meditarráneo- reciben influencias recíprocas ${ }^{184}$. Los cambios motivados por los contactos exteriores tuvieron también consecuencias para la población. En el momento en que la sociedad del Occidente hispánico buscaba nuevas formas de representación, el carro figuró sin duda entre las atracciones más relevantes, sobre todo, porque en el siglo VII a. C., tanto en Europa Central como en el área del Meditarráneo, los carros no se utilizaban mayoritariamente para la guerra, sino para competir en las carreras y como símbolo de distinción. En las dos áreas geográficas citadas, el carro estaba relacionado tradicionalmente con la forma de vida aristocrática y, por ello, su representación era una forma de señalar el estatus social de una persona. A los carros va unida tanto la migración de ideas y conceptos de valores como la introducción de nuevas formas, funciones, detalles técnicos, decoraciones, etc. En contra de lo que la investigación creía hasta ahora, las representaciones de carros y los carros con copa propiamente dichos no proceden de una misma fuente -el área greco-fenicio-mediterráneo-oriental ${ }^{185}$, sino también del entorno centroeuropeo y, en concreto, de las culturas de los Campos de Urnas y Hallstatt. Los carros con copa de Baiões ofrecen el mejor ejemplo de ello, ya que sus antecesores más cercanos se encuentran al sur de los Alpes, en la Lombardía del norte de Italia. Como emplazamiento cabe pensar más en santuarios que en tumbas. equivalente, que unía el noreste y el oeste hispánicos con el suroeste; v. Senna-Martínez 1994, 227.

${ }^{181}$ Los $18 \mathrm{~kg}$ escasos que constituyen el peso total del depósito de Baiões resulta sorprendente, sobre todo, porque en las restantes excavaciones de la Beira Alta casi nunca se han extraído más de unos pocos centenares de gramos de bronce; v. Senna-Martínez 2005, 906-909.

${ }^{182}$ Coffyn 1985, 267 »groupe lusitanien«; Senna-Martínez 2005, 906. 909; Vilaça 2008, 119 (con bibliografía más antigua).

183 Kalb 1978, 126.

${ }^{184}$ Senna-Martínez 2005, 906; Vilaça 2008, 82.

185 Celestino Pérez 2001, 230. 
Tab. 1. Relación de las características chipriotas y centroeuropeas de los carros con copa.

\begin{tabular}{|c|c|c|c|c|c|c|c|c|c|c|c|c|}
\hline \multicolumn{2}{|c|}{ Características } & \multicolumn{6}{|c|}{ Chipriota-orientales } & \multicolumn{5}{|c|}{ Centroeuropeas } \\
\hline & & $\begin{array}{l}\text { Estructura } \\
\text { de caja } \\
\text { cuadrado- } \\
\text { rectangular }\end{array}$ & $\begin{array}{l}\text { Barras de } \\
\text { soporte } \\
\text { verticales } \\
\text { en las } \\
\text { esquinas } \\
\text { que } \\
\text { terminan } \\
\text { en ojales }\end{array}$ & $\begin{array}{l}\text { Láminas } \\
\text { metálicas } \\
\text { con } \\
\text { calado }\end{array}$ & $\begin{array}{l}\text { Cordón } \\
\text { con } \\
\text { relieve } \\
\text { de cuerda } \\
\text { trenzada }\end{array}$ & Figuras & $\begin{array}{l}\text { Recipiente } \\
\text { con } \\
\text { costillas }\end{array}$ & $\begin{array}{l}\text { Eje } \\
\text { vertical } \\
\text { central }\end{array}$ & $\begin{array}{l}\text { Barras de } \\
\text { soporte } \\
\text { diagonales }\end{array}$ & $\begin{array}{l}\text { Varillas } \\
\text { torsionadas }\end{array}$ & $\begin{array}{l}\text { Cubo de } \\
\text { rueda } \\
\text { engrosado }\end{array}$ & $\begin{array}{l}\text { Elementos } \\
\text { colgantes } \\
\text { sonoros }\end{array}$ \\
\hline 1 & $\begin{array}{l}\text { Enkomi } \\
\text { (Chipre) }\end{array}$ & $\bullet$ & $\bullet$ & $\bullet$ & $\bullet$ & $\bullet$ & $\bullet$ & & & & & \\
\hline 2 & Skallerup & & & & & & & $\bullet$ & & $\bullet$ & $\bullet$ & $\bullet$ \\
\hline & $\begin{array}{l}\text { Sesto } \\
\text { Calende }\end{array}$ & & & & & & & $\bullet$ & & & $\bullet$ & $\bullet$ \\
\hline 3 & Bisenzio & & $\bullet$ & $\bullet$ & $\bullet$ & $\bullet$ & & & $\bullet$ & & $\bullet$ & \\
\hline & Strettweg & & & $\bullet$ & & $\bullet$ & & $\bullet$ & $\bullet$ & $\bullet$ & $\bullet$ & \\
\hline & $\begin{array}{l}\text { Como- } \\
\text { Ca'Morta }\end{array}$ & & & & & & $\bullet$ & & $\bullet$ & $\bullet$ & $\bullet$ & \\
\hline 4 & $\begin{array}{l}\text { Rueda de } \\
\text { Baiões 1+ }\end{array}$ & $\bullet$ & $\bullet$ & $\bullet$ & $\bullet$ & & & & $\bullet$ & & & $\bullet$ \\
\hline & $\begin{array}{l}\text { Rueda de } \\
\text { Baiões 2+ }\end{array}$ & & & $\bullet$ & & & $\bullet$ & $\bullet$ & & & & \\
\hline & $\begin{array}{l}\text { Rueda de } \\
\text { Baiões } 3+\end{array}$ & & & $\bullet$ & & & $\bullet$ & & & & $\bullet$ & \\
\hline
\end{tabular}

\section{Bibliografía}

ACOSTA 1968: P. Acosta, La pintura rupestre esquemática en España (Salamanca 1968).

AHLBERG 1971: G. Ahlberg, Prothesis and ekphora in Greek Geometric Art, Studies in Mediterranean Art 32 (Göteborg 1971).

ALLISON 2009: P. M. Allison, "The Mediterranean after Braudel and Horden-Purcell”, Journal of Roman Studies 22, 2009, 461-465.

ALMAGRO 1966: M. Almagro, Las estelas decoradas del suroeste peninsular, Bibliotheca Praehistorica Hispana 8 (Madrid 1966).

ALMAGRO-GORBEA 1989: M. Almagro-Gorbea, “Arqueología e Historia Antigua. El proceso protoorientalizante y el inicio de los contactos de
Tartessos con el levante mediterráneo, in: Estudios sobre la Antigüedad", en Homenaje al profesor Santiago Montero Díaz, Gerión Anejo II (Madrid 1989) 277-288.

ALMAGRO-GORBEA 1992: M. Almagro-Gorbea, "Los intercambios culturales entre Aragón y el litoral mediterráneo durante el Bronce Final", in: P. Utrilla Miranda (Hrsg.), Aragón/Litoral Mediterráneo. Intercambios culturales durante la Prehistoria. En homenaje a Juan Maluquer de Motes. Ponencias y comunicaciones (Zaragoza 1992) 633-658.

ALMAGRO-GORBEA 1993: M. Almagro-Gorbea, "La introducción del hierrro en la Península Ibérica. Contactos precoloniales en el periodo protoorientalizante", Complutum 4, 1993, 81-94. 
ALMAGRO-GORBEA 1996: M. Almagro-Gorbea, "Sacred Places and Cults of Late Bronze Age Tradition in Celtic Hispania", in: P. Schauer (Hrsg.), Archäologische Forschungen zum Kultgeschehen in der Jüngeren Bronzezeit und Frühen Eisenzeit Alteuropas. Ergebnisse eines Kolloqiums in Regensburg 4.-7. Oktober 1993, Regensburger Beiträge zur Prähistorischen Archäologie 2 (Regensburg 1996) 43-79.

ALMAGRO-GORBEA 1998: M. Almagro-Gorbea, "Precolonización" y cambio socio-cultural en el Bronze Atlántico, in: S. Oliveira Jorge (Hrsg.), Existe uma idade do bronze atlântico? Coloquio en Lisboa del 12 al 14 de octubre de 1995 (=Trabalhos de Arqueología 10) 1998, 81-100.

ALMAGRO-GORBEA 2000: M. Almagro-Gorbea, "La precolonización fenicia" en la Península Ibérica", in: Actas del IV Congreso Internacional de Estudios Fenicios y Púnicos, Cádiz 2 al 6 de Octubre de 1995 II (Cádiz 2000) 711-721.

ARMADA-RAFEL-MONTERO 2008: X.L. Armada N. Rafel - I. Montero, "Contactos precoloniales, actividad metalúrgica y biografías de objetos de bronce en la Península Ibérica”, en: S. Celestino N. Rafel - X.L.

ARMADA-ROVIRA 2011: X.L. Armada - S. Rovira, "El soporte de les Ferreres de Calaccite (Teruel): Una revisión desde su tecnología y contexto", AEspA 84, 2011, 9-41.

ARMBRUSTER 2000: B. R. Armbruster, Goldschmiedekunst und Bronzetechnik. Studien zum Metallhandwerk der Atlantischen Bronzezeit auf der Iberischen Halbinsel (=Monographies Instrumentum 15) (Montagnac 2000).

ARMBRUSTER 2003: B. Armbruster, A metalurgia da Idade do Bronze Final Atlântico do Castro de Nossa Senhora da Guía, de Baiões (S. Pedro do Sul, Viseu), Estudos Pré-Históricos 10/11, 2002/2003, 145-155.

ARNAL - PRADES 1976: J. Arnal - H. Prades, L'art de la civilisation des champs d'urnes et les chars processionels en France, in : $\mathrm{IX}^{\mathrm{e}}$ Congrès Union Internationale des Sciences Préhistoriques et Protohistoriques, E. Anati (dir.), Colloque XXVII Les gravures protohistoriques dans les Alpes, Saint-Dalmas-de-Tende 20 septembre 1976 (Nice 1976) 39-51.

ARTEAGA - SCHUBART 1980: O. Arteaga - H. Schubart, Fuente Álamo. Excavaciones de 1977, Noticiario Arqueológico Hispánico 9, 1980, 245-289.

AUBERT 1992: C. Aubert, La période préphénicienne en Péninsule Ibérique. Relations avec la Méditerrrané Centrale, Mélanges de la Casa de Velázquez 28, 1992, 7-18.
BARNETT 1957: R. D. Barnett, A Catalogue of the Nimrud Ivories with Other Examples of Ancient Near Eastern Ivories in the British Museum (London 1957).

BEBA 2008: S. Beba, Die tartessischen "Fürstengräber" in Andalusien, Bochumer Forschungen zur ur- und frühgeschichtlichen Archäologie 1 (Rahden 2008).

BENDALA GALÁN 1977: M. Bendala Galán, Notas sobre las estelas decoradas del suroeste y los orígenes de Tartessos, Habis 8, 1977, 177-205.

BENDALA GALÁN 1979: M. Bendala Galán, Las más antiguas navegaciones griegas a España y el origen de Tartessos, AEspA 52, 1979, 33-38.

BERG-OSTERRIETH 1972: M. van Berg-Osterrieth, Les chars prehistoriques du Val Camonica, Archivi 3 (Brescia 1972).

BETTENCOURT 1995: A. Bettencourt, Dos inícios aos finais da Idade do Bronze no Norte de Portugal, S. Oliveira Jorge (ed.), A Idade do Bronze em Portugal - Discursos de poder (Lisboa 1995) 110-115.

BETTENCOURT 2001: A. M. S. Bettencourt, O povoado da Santinha, Amares, Norte de Portugal, nos finais da Idade do Bronze, Cadernos de Arqueología Monografías 12 (Braga 2001).

BRANDHERM 2009: D. Brandherm, Sobre los supuestos arreos de caballo y piezas de carro de la Ría de Huelva, Boletín de la Asociación Española de Amigos de la Arqueología 45, 2008/09, 27-34.

BRAUDEL 1993: F. Braudel, La méditerranée et le monde méditerranéen à l'époque de Philippe $\mathrm{II}^{3}$ (Paris 1993).

BREUIL 1933: H. Breuil, Les peintures rupestres schématiques de la Péninsule Ibérique. II Bassin du Guadiana (Paris 1933).

BURGESS 1991: C. Burgess, The East and the West. Mediterranean Influence in the Atlantic World in the Later Bronze Age, c. 1500-700 B.C., en: C. Chevillot - A. Coffyn (dir.), L'Age du Bronze Atlantique, ses faciès, de l'Écosse à l'Andalousie et leurs relations avec le Bronze Continental et la Méditerranée. Actes du $1^{\text {er }}$ Colloque du Parc Archéologique de Beynac (Beynac-et-Cazenac 1991) 25-45.

CALO LOURIDO 2003: F. Calo Lourido, Catálogo, Madrider Mitteilungen 44, 2003, 6-32.

CARBALLO ARCEO 2003: L. X. Carballo Arceo, La dorsal gallega como barrera intracultural durante la Edad del Hierro, Madrider Mitteilungen 44, 2003, 333-345. 
CELESTINO PÉREZ 1985: S. Celestino Pérez, Los carros y las estelas decoradas del suroeste. Homenaje a Cánovas Pessini. Estudios de Arqueología Extremeña (Badajoz 1985) 45-55.

CELESTINO PÉREZ 2001: S. Celestino Pérez, Estelas de guerrero y estelas diademadas. La precolonización y formación del mundo tartésico (Barcelona 2001).

CHAPA 2003: T. Chapa, El Bronce Final y la Edad del Hierro, en: G. Vega et al, La Prehístoria. Historia de España 3er. milenio 1. Síntesis (Madrid 2003) $175-247$

COFFYN 1985: A. Coffyn, Le Bronze Final Atlantique dans la Péninsule Ibérique. Publications du Centre Pierre Paris 11, Collection de la Maison des Pays Ibériques 20 (Paris 1985).

COFFYN - GOMEZ - MOHEN 1981: A. Coffyn - J. Gomez - J.-P. Mohen, L'apogée du Bronze Atlantique. Le dépôt de Vénat (Paris 1981).

COFFYN - SION 1993: A. Coffyn - H. Sion, Les relations atlanto-méditerranées. Eléments pour une révision chronologique du Bronze Final atlantique, in: Actas do $1^{\circ}$ Congresso Mediterrânico de Etnología Histórica, Lisboa 4 a 8 de novembro de 1991 (=Mediterrâneo 2) (Lissabon 1993) 285-310.

CORREIA 2001: V. H. Correia, O povoamento do noroeste no $\mathrm{I}^{\circ}$ millenio a. C., in : L. BerrocalRangel - Ph. Gardes, Entre celtas e íberos. Las poblaciones protohistóricas de las Galias e Hispania. Las poblaciones protohistóricas de las Galias e Hispania. Actas de la Mesa Redonda en Madrid los dias 12 y 13 de enero de 1998 (=Bibliotheca Archaeologica Hispana 8) (Madrid 2001) 213-226.

CORREIA 2009: V. Hippólito Correia, Ein goldenes Pektoral aus Castro Marim (Distr. Faro, Portugal), Madrider Mitteilungen 50, 2009, 71-79.

CRUZ 1997: D. J. Cruz, A necrópole do Bronze Final do "Paranho" (Molelos, Tondela, Viseu), Estudos Pré-históricos 5, 1997, 85-109.

CRUZ - VILAÇA 1999: D. J. da Cruz - R. Vilaça, O grupo de Tumuli da "Senhora da Ouvida" (Monteiras/Moura Morta, Castro Daire, Viseu). Resultados dos trabalhos arqueológicos, Estudos Pré-históricos 7, 1999, 129-161.

DELIBES - FERNÁNDEZ-MANZANO - CELIS 1992/93: G. Delibes - J. Fernández-Manzano - J. Celis, Nuevos "Ganchos de carne" protohistóricos de la Península Ibérica. Homenaje a Manuel Pellicer Catalán, Tabona 8 II,1992/93, 417-434.
EGG 1991: M. Egg, Ein neuer Kesselwagen aus Etrurien (mit einem Beitrag von L. Lehóczky), Jahrbuch des Römisch-Germanischen Zentralmuseums Mainz 38, 1991(1), 191-222

EGG 1996: M. Egg, Das hallstattzeitliche Fürstengrab von Strettweg bei Judenburg in der Obersteiermark, Römisch - Germanisches Zentralmuseum Mainz Monographien 17 (Mainz 1996).

EGG 2001: Reallexikon der Germanischen Altertumskunde 17 (Berlin 2001) 463-470 s. v. Kultwagen (M. Egg).

FERNÁNDEZ CASTRO 1988: M. C. Fernández Castro, Arqueología protohistórica de la Península Ibérica (siglos X a VIII a. C.) (Madrid 1988).

FERNÁNDEZ MIRANDA - OLMOS 1986: M. Fernández Miranda - R. Olmos, Las ruedas de Toya. El origen del carro en la Península Ibérica (1986), Museo Arqueológico Nacional, Catálogos y monografías 9 (Madrid 1986).

FLESS 2002: F. Fless, Rotfigurige Keramik als Handelsware. Erwerb und Gebrauch attischer Vasen im mediterranen und pontischen Raum während des 4. Jhs. v. Chr. (=Internationale Archäologie 71) (Rahden 2002).

FREY 1980: O.-H. Frey, Der Westhallstattkreis im 6. Jh. v. Chr., in: Die Hallstatt-Kultur. Frühform europäischer Einheit. Catálogo de la exposición Steyr (Linz 1980) 80-116.

FURTW ÄNGLER 1893: A. Furtwängler, Meisterwerke der griechischen Plastik. Kunstgeschichtliche Untersuchungen (LeipzigBerlin 1893).

GABROVEC 1980: S. Gabrovec, Der Beginn der Hallstattkultur und der Osten, in: Die HallstattKultur. Frühform europäischer Einheit. Catálogo de la exposición Steyr (Linz 1980) 30-53.

GONZÁLEZ DE CANALES 2004: F. González de Canales Cerisola, Del occidente mítico griego a Tarsis-Tarteso. Fuentes escritas y documentación arqueológica (Madrid 2004).

GONZÁLEZ RUIBAL 2007: A. González Ruibal, “La vida social de los objetos castreños”, en: F. J. González garcía (ed.), los pueblos de la Galicia céltica (Madrid 2007), 259-322

GUGGISBERG 1996: M. Guggisberg, Eine Reise von Knossos nach Strettweg. Tiergefässe und Kesselwagen als Ausdruck religiöser Kontakte zwischen der Ägäis und Mitteleuropa im frühen 1. Jahrtausend v. Chr., Archäologischer Anzeiger 1996, 175-195. 
HARRIS 2005: W. V. Harris (ed.), Rethinking the Mediterranean (Oxford 2005).

HARRISON 2004: R. J. Harrison, Symbols and warriors: images of the European Bronze Age (Bristol 2004).

HÖCKMANN 1982: U. Höckmann, Die Bronzen aus dem Fürstengrab von Castel San Mariano bei Perugia. Staatliche Antikensammlungen München, Katalog der Bronzen I (hrsg. von K. Vierneisel) (München 1982).

HORDEN - PURCELL 2000: P. Horden - N. Purcell, The Corrupting Sea. A Study of Mediterranean History (Oxford 2000).

JIMÉNEZ ÁVILA 2003: J. Jiménez Ávila, Las sandalias de Apolo. Sobre el origen griego de los cinturones "célticos", Archivo Español de Arqueología 76, 2003, 31-46.

JORGE 1998: S. Oliveira Jorge (ed.), Existe uma idade do Bronze Atlântico?, Trabalhos de Arqueología 10 (Lisboa 1998).

JOYA GUERRERO 1998: J. Joya Guerrero, El carro y su función social durante el Bronce Final y el Orientalizante en el suroeste de la Península Ibérica. Una revisión necesaria, Spal 7, 1998, 81-92.

KALB 1978: Ph. Kalb, Senhora da Guia, Baiões. Die Ausgrabung 1977 auf einer Höhensiedlung der Atlantischen Bronzezeit in Portugal, Madrider Mitteilungen 19, 1978, 112-138.

KALB 1991: Ph. Kalb, Die Goldringe vom Castro Senhora da Guia, Baiões (Co. São Pedro do Sul), Portugal, in: Festschrift für Wilhelm Schüle zum 60. Geburtstag überreicht von seinen Schülern und Freunden, Veröffentlichungen des Vorgeschichtlichen Seminars Marburg, Sonderband 6, Internationale Archäologie 1 (Buch am Erlbach 1991) 185-200 (portugies. Version in O Arqueólogo Português Sér. IV 8/10, 1990-92, 259-276).

KALB 1993: Ph. Kalb, Schatzfunde der Bronzezeit, in: H. Schubart - A. Arbeiter-S. Noack-Haley (Hrsg.), Funde in Portugal (Göttingen 1993) 87-102.

KAUL 2001: Reallexikon der Germanischen Altertumskunde 17 (Berlin 2001) 470-478 s. v. Kultwagen (F. Kaul).

LO SCHIAVO - MACNAMARA - VAGNETTI 1985: F. Lo Schiavo - E. Macnamara - L. Vagnetti, Late Zypriot Imports to Italy and Their Influence on Local Bronzework, Papers of British School at Rome 51, 1985, 1-71.

MANSEL 1998: K. Mansel, Studien zum Trachtzubehör der älteren Eisenzeit am Golfe du Lion und im Ampurdán, Internationale Archäologie 32 (Rahden/Westf. 1998).
MARTINS 1988: M. Martins, A citânia de S. Julião, Cadernos de Arqueología, Monografías 2 (Braga 1988).

MATTHÄUS 1985: H. Matthäus, Metallgefäße und Gefäßuntersätze der Bronzezeit, der geometrischen und archaischen Periode auf Zypern, Prähistorische Bronzefunde II/8 (München 1985).

MEDEROS - HARRISON 1996: A. Mederos - R. J.Harrison, "Placer de dioses". Incensarios en soportes con ruedas del Bronce Final de la Península Ibérica, en: $\mathrm{M}^{\mathrm{a}}$. A. Querol - T. Chapa (eds.), Homenaje al Profesor Manuel FernándezMiranda I (=Complutum Extra 6) (Madrid 1996) 237-254.

MEDEROS 2008: A. Mederos Martín, Carros micénicos del Heládico Final III en las estelas decoradas del Bronce Final II-IIA del Suroeste de la Península Ibérica, in: S. Celestino Pérez - N. Rafel - X.-L. Armada (eds.), Contacto cultural entre el Mediterrâneo y el Atlántico (siglos XII-VIII ane). La Precolonización a debate, Serie Arqueológica de la Escuela Española de Historia y Arqueología en Roma 11 (Madrid 2008) 437-463.

MEDEROS 2009: A. Mederos Martín, Metal para los dioses. La secuencia del grupo Baiões durante el Bronce Final II y el comercio chipriota de hierro hacia Portugal (1200-1050 AC), in: R. CruzAuñón Briones - E. Ferrer Albelda (coord.), Estudios de Prehistoria y Arqueología en Homenaje a Pilar Acosta Martínez (Sevilla 2009) 279-304.

MEIJIDE CAMESELLE 1988: G. Meijide Cameselle, Las espadas del Bronce Final en la Península Ibérica, Arqueohistorica Nr. 1 (Santiago de Compostela 1988).

NEUMAIER 1995A: J. Neumaier, Los Campos de Urnas del sudoeste europeo desde el punto de vista centroeuropeo, Revista d'Arqueología de Ponent 5, 1995, 53-80.

NEUMAIER 1995B: J. Neumaier, Eine iberische Fundgruppe Südwestdeutschlands in der Späthallstattzeit, Germania 73/2, 1995, 495-503.

NEUMAIER 1996: J. Neumaier, Colgantes zoomorfos de las costas valenciana y catalana, Quaderns de Prehistòria i Arqueologia de Castelló 17, 1996, 255-261.

PARE 1987: Chr. F. E. Pare, Der Zeremonialwagen der Bronze- und Urnenfelderzeit. Seine Entstehung, Form und Verbreitung, in: Vierrädrige Wagen der Hallstattzeit. Untersuchungen zu Geschichte und Technik (=Römisch-Germanisches Zentralmuseum Mainz Monographien 12) (Mainz 1987) 25-67. 
PARZINGER 1991: H. Parzinger, Inandiktepe - Este Pozo Moro. Bemerkungen zur frühen Bilderzählung, Bericht der RömischGermanischen Kommission 72, 1991, 5-44.

PEDRO 2000: Y. Pedro, O Castro da Senhora da Guia (S. Pedro do Sul, Viseu), in: Catálogo de la exposición. Viseu (Viseu 2000) 132-135.

QUESADA - BLÁZQUEZ 2005: F. Quesada Sanz - J M. Blázquez Martínez, Los carruajes de los orígenes al final de la Antigüedad. Carros en el antiguo mediterráneo. De los orígenes a Roma, in: E. Galán Domingo (coord.), Historia del carruaje en España (o. Ort 2005) 16-71.

ROLLEY 1977: C. Rolley, Les trépieds à cuve clouée, Fouilles de Delphes V, 3 (Paris 1977).

ROUILLARD 2009: P. Rouillard, La méditerranée, avec ou après Braudel, Boletín de la Asociación Española de Amigos de la Arqueología 45, 2008/09, 51-54.

ROVIRA 1995: S. Rovira, Estudio arqueometalúrgico del depósito de la Ría de Huelva, in: M. RuizGálvez Priego (ed.), Ritos de paso y puntos de paso. La Ría de Huelva en el mundo del Bronce Final Europeo, Complutum extra 5 (Madrid 1995) 33-57.

RUIZ-GÁLVEZ 1993: M. Ruiz-Gálvez Priego, El occidente de la Península Ibérica. Punto de encuentro entre el Mediterráneo y el Atlántico a fines de la Edad del Bronce, Complutum 4, 1993, 41-68.

RUIZ-GÁLVEZ 1995: M. Ruiz-Gálvez Priego, El significado de la Ría de Huelva en el contexto de las relaciones de intercambio y de las transformaciones producidas en la transición Bronce Final/Edad del Hierro, in: M. Ruiz-Gálvez Priego (Hrsg.), Ritos de paso y puntos de paso. La Ría de Huelva en el mundo del Bronce Final Europeo, Complutum extra 5 (Madrid 1995) 129-155.

RUIZ-GÁLVEZ 1998: M. Ruiz-Gálvez Priego, La Europa Atlántica en la Edad del Bronce (Barcelona 1998).

RUIZ-GÁLVEZ 2005: M. Ruiz-Gálvez Priego, Der fliegende Mittelmeermann. Piratas y héroes en los albores de la Edad del Hierro, in: S. Celestino Pérez - J. Jiménez Ávila (Hrsg.), El período orientalizante. Actas del Simposio Internacional de arqueología de Mérida >Protohistoria del Mediterráneo Occidental< (=Anejos de Archivo Español de Arqueología 35) (Mérida 2005) 251-275.

SCHATTNER 2007: Th. G. Schattner, Die Fundkeramik vom 8. bis zum 4.Jh.v.Chr. Didyma III 4 (Mainz 2007).
SCHATTNER - SANTOS - PEREIRA 2008: Th. Schattner - M. J. Santos - V. Pereira, Cabeço das Fraguas (Guarda), 2006. O contributo da primeira campanha de escavação, Praça Velha 24, 2008, 175-202.

SCHAUER 1987: P. Schauer, Der vierrädrige Wagen in Zeremonialgeschehen und Bestattungsbrauch der orientalisch-ägäischen Hochkulturen und ihrer Randgebiete, in: Vierrädrige Wagen der Hallstattzeit, Untersuchungen zu Geschichte und Technik, Römisch-Germanisches Zentralmuseum Mainz Monographien 12 (Mainz 1987) 1-23.

SENNA-MARTINEZ 1993: J. C. de Senna-Martinez, O grupo Baiões/Santa Luzia. Contribuições para uma tipología da olaria, Trabalhos de Arqueologia da EAM 1, 1993, 93-123.

SENNA-MARTINEZ 1994: J. C. de Senna-Martinez, Entre Atlântico e Mediterrâneo. Algumas reflexões sobre o Grupo Baiões/Santa Luzia e o desenvolvimento do Bronze Final Peninsular, Trabalhos de Arqueología da EAM 2, 1994, 215-232.

SENNA-MARTINEZ 2000A: J. C. de SennaMartinez, O "Grupo Baiões/Santa Luzia" no Quadro do Bronze Final do Centro de Portugal, in: Catálogo de la exposición. Viseu (Viseu 2000) 119-134.

SENNA-MARTINEZ 2000B: J. C. de SennaMartinez, Between Myth and Reality. The Foundry Area of Senhora da Guia de Baiões and Baiões/Santa Luzia Metallurgy, Trabalhos de Arqueologia da EAM 6, 2000, 61-77.

SENNA-MARTINEZ -ARAÚJO - VALÉRIO PEIXOTO 2004: J. C. de Senna-Martinez - M. F. Araújo - P. Valério - H. Peixoto, Estudos sobre a arqueometalurgia do grupo Baiões/Santa Luzia. 1. Uma ponta de lança do Castro da Senhora das Necessidades (Sernancelhe), O Arqueólogo Português Sér. IV 22, 2004, 319-331.

SENNA-MARTINEZ 2005: J. C. de Senna-Martinez, O outro lado do comércio orientalizante. Aspectos da produção metalúrgica no polo indígena, o caso das Beiras Portuguesas, in: S. Celestino Pérez - J. Jiménez Ávila (eds.), El período orientalizante. Actas del III Simposio Internacional de Arqueología de Mérida >Protohistoria del Mediterráneo Occidental< (=Anejos de Archivo Español de Arqueología 35) (Mérida 2005) 901-910.

SEVILLANO 1976: M. C. Sevillano San José, Grabados rupestres de carros y ruedas en Vegas de Coria (Cáceres), Zephyrus 26/27, 1976, 257-267. 
SILVA 1979: C. T. Silva, O Castro de Baiões (S. Pedro do Sul), Beira Alta 38, 1979, 511-531.

SILVA - SILVA - LOPES 1984: A. Coelho Ferreira da Silva - C. Tavares da Silva - A. Baptista Lopes, Depósito de fundidor do final da Idade do Bronze do Castro da Senhora da Guia (Baiões, S. Pedro Sul, Viseu), En: Lucerna. Homenagem a D. Domingos de Pinho Brandão (Porto 1984) 73-110.

SILVA - GOMES 1992: A. Coelho Ferreira da Silva M. Varela Gomes, Proto-História de Portugal (Lisboa 1992).

STARY 1994: P. F. Stary, Zur eisenzeitlichen Bewaffnung und Kampfesweise auf der Iberischen Halbinsel, Madrider Forschungen 18 (Berlin - New York 1994)

ULISSES 1996: De Ulisses a Viriato. O primeiro milénio a.C., Catálogo de la exposición. Lissabon (Lisboa 1996).

VALÉRIO - ARAÚJO - SENNA-MARTINEZ INÊS VAZ 2006: P. Valério - M. F. Araújo - J. C. Senna-Martinez - J. L. Inês Vaz, Caracterização química de produções metalúrgicas do Castro da Senhora da Guia de Baiões (Bronze Final), $O$ Arqueólogo Português Sér. IV 24, 2006, 289-319.

VILAÇA 1997: R. Vilaça, Metalurgia do Bronze Final da Beira Interior. Revisão dos dados à luz de novos resultados, Estudos Pré-Históricos 5, 1997, $123-154$.

VILAÇA - CRUZ 1999: R. Vilaça - D. J da Cruz, Práticas funerárias e cultuais dos finais da Idade do Bronze na Beira Alta, Arqueología 24, 1999, 73-99.

VILAÇA - BECK - STOUT 2002: R. Vilaça - C. Beck - E. C. Stout, Provenience Analysis of Prehistoric Amber Artifacts in Portugal, Madrider Mitteilungen 43, 2002, 61-78.

VILAÇA 2007: R. Vilaça, A Cachouça (Idanha-aNova, Castelo Branco). Construção e organização de um caso singular de inícios do I milénio AC. Actas do IV Congresso de Arqueología Peninsular (Faro 2007) 67-75.

VILAÇA 2008: R. Vilaça, Através das Beiras, PréHistória e Proto-História (Coimbra 2008). Se trata de una compilación de diferentes obras de esta autora:

VILAÇA 2008, 13-38: R. Vilaça, Registos e leituras da Pré-história Recente e da Proto-História Antiga da Beira Interior, En: Actas do $3^{\circ}$ Congresso de Arqueología Peninsular IV (Porto 2000) 161-182.
VILAÇA 2008, 65-85: R. Vilaça, Entre Ouro e Tejo, por terras do interior. O I milénio a. C., En: Lusitanos e Romanos no Nordeste da Lusitania. Actas das $2^{\text {as }}$ Jornadas de Património da Beira Interior (Guarda 2005) 13-32.

VILAÇA 2008, 87-104: R. Vilaça, Notas soltas sobre o Património arqueológico do Bronze Final da Beira interior, En: Beira Interior, história $e$ patromónio. Actas das I ${ }^{\text {as }}$ Jornadas de Património da Beira Interior (Guarda 2000) 31-50.

VILAÇA 2008, 105-159: R. Vilaça, Reflexões em torno da "presença mediterrânea" no centro do território português. Na charneira do Bronze Final para o Ferro, in: S. Celestino Pérez - N. Rafel X.-L. Armada (Hrsg.), Contacto cultural entre el Mediterrâneo y el Atlántico (siglos XII-VIII ane). La Precolonización a debate, Serie Arqueológica de la Escuela Española de Historia y Arqueología en Roma 11 (Madrid 2008) 371-400.

VILAÇA 2008, 161-193: R. Vilaça, Acerca da existência de ponderais em contextos do Bronze Final/Ferro Inicial no território português, O Arqueólogo Português (Ser. 4) 21, 2003, 245-288.

VILAÇA 2008, 195-220: R. Vilaça, Artefactos de Ferro em contextos do Bronze Final do território português. Novos contributos e reavaliação dos dados, Complutum 17, 2006, 81-101.

WEIPPERT 2006: H. Weippert, Die Kesselwagen Salomos, in: H. Weippert, Unter Olivenbäumen. Studien zur Archäologie Syrien-Palästinas, Kulturgeschichte und Exegese des Alten Testaments Gesammelte Aufsätze. Festgabe zum 4. Mai 2003 (hrsg. von A. Berlejung und H. M. Niemann) (Münster 2006) 71-114.

WOYTOWITSCH 1978: E. Woytowitsch, Die Wagen der Bronze- und frühen Eisenzeit in Italien, Prähistorische Bronzefunde XVII,1 (München 1978) . 
